\title{
Variation and evolutionary transformation of some characters of the pollinarium and pistil in Epidendroideae (Orchidaceae)
}

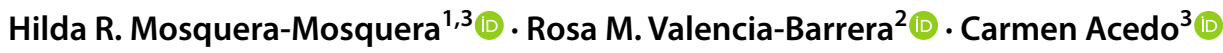

Received: 24 June 2018 / Accepted: 21 March 2019 / Published online: 8 April 2019

(c) The Author(s) 2019

\begin{abstract}
We studied the variation in the pollinarium and pistil of Epidendroideae and reconstructed the ancestral states of the characters (pollinia number, pollinium orientation, pollinium with suture, and pollinium texture). The pollinarium is complete (formed by pollinium, caudicle, stipe, and viscidium) in Vandeae, Epidendreae, and Cymbidieae, but the caudicle is absent in some Aeridinae and the viscidium in Laeliinae and Pleurothallidinae. Neottieae, Arethuseae, Sobralieae, Epidendreae, and Xerorchideae included some genera having sessile pollinia. The more frequent state in the family is to have two pollinia, followed by four, eight, and six pollinia. The pistil is unilocular, although it seems to have experienced reversals several times within Epidendroideae because intermediate states were observed (e.g. Vanda and Angraecum). In these cases, a prolongation of the placental tissue is developed that in Huntleya and Peristeria make contact but do not fuse. Most members of the subfamily have pistil composed of three carpels divided into six emerging valves, but only three are fertile. In Cattleya and Sophronitis the sterile valves are much reduced and the pistil seems to have only three valves. We have generated useful and valuable information to understand the evolution of the reproductive organs in Epidendroideae. Probably, these transformations in the pollinarium and pistil have co-evolved in tandem with pollinators to make the pollination more efficient. Our results suggest that the common ancestor of Epidendroideae had a complete pollinarium, formed probably of four juxtaposed granular pollinia without suture, bearing caudicle, tegular stipe and viscidium, but several early transformations occurred during the Epidendroideae diversification.
\end{abstract}

Keywords Carpels $\cdot$ Epidendroideae $\cdot$ Evolution $\cdot$ Locules $\cdot$ Pollinarium $\cdot$ Pollinia

Handling Editor: Louis P. Ronse De Craene.

Electronic supplementary material The online version of this article (https://doi.org/10.1007/s00606-019-01575-5) contains supplementary material, which is available to authorized users.

Hilda R. Mosquera-Mosquera

hrmosqueram@ut.edu.co

1 Department of Biology, Research Group Plant and Microbial Biotechnology - GEBIUT, Faculty of Sciences, University of Tolima, PO Box 730006299, Ibagué, Colombia

2 Department of Biodiversity and Environment Management, Botany, Research Group Aerobiology - AERULE, University of León, 24071 León, Spain

3 Department of Biodiversity and Environment Management, Botany, Research Group Taxonomy and Biodiversity Conservation - TaCoBi, Faculty of Biological and Environmental Sciences, University of León, 24071 León, Spain

\section{Introduction}

Epidendroideae is the largest subfamily of Orchidaceae having more genera and species than all the others together. It is characterized by its variety and diversity of forms (Kułak et al. 2006), including several phylogenetically advanced and morphologically derived tribes and subtribes (Chase et al. 2003, 2015). Recently, Freudenstein and Chase (2015) analysed the phylogenetic relationships in Epidendroideae and progressive specialization and diversification including morpho-anatomical characters, habit and distribution together with DNA sequences.

Only Epidendroideae and Orchidoideae, among the five subfamilies of Orchidaceae, present authentic pollinia and pollinarium (Singer et al. 2008), both subfamilies are also the richest in the number of species and genera (Chase et al. 2003), and important contributions have been made to their phylogenies (for example, Inda et al. 2010, 2012; Chase et al. 2015). Some traits of the pollinarium of Epidendroideae 
and Orchidoideae have been previously studied (Schill and Pfeiffer 1977; Dressler 1981, 1993; Rasmussen 1982; Blackman and Yeung 1983; Burns-Balogh and Funk 1986; Yeung and Law 1987; Seidenfaden and Wood 1992; Freudenstein 1994; Freudenstein and Rasmussen 1996, 1997; Claessens and Kleynen 1998; Johnson and Edwards 2000; Szlachetko and Rutkowski 2000; Freudenstein et al. 2002; Szlachetko and Margońska 2002; Szlachetko 2003; Barone Lumaga et al. 2006; Bhanwra et al. 2006; Hidayat et al. 2006; Szlachetko et al. 2006; Rothacker 2007; Singer et al. 2008; Nieto and Damon 2008; Chase 2009; Chase et al. 2009; Szlachetko and Mytnik-Ejsmont 2009; Damon and Nieto 2012; Szlachetko et al. 2012; Pedersen et al. 2013; Freudenstein and Chase 2015; Freudenstein et al. 2017). However, there is still little information about the states of each character and the evolutionary pathways related to the pollinarium of the Epidendroideae, which is probably the subfamily having greater variability in this structure. Therefore, here we improve the pollinia description, by studying details of the accessory structures because most of the available descriptions in the literature available are oversimplified or lack this information.

The pollinaria are a key innovation in the evolutionary history of Orchidaceae and probably contribute to the diversification of this important family. Strategies such as the compaction grades of pollen grains and the presence of accessory structures (caudicle, stipe, and viscidium) provide easier transport by pollinators (Johnson and Edwards 2000). The number of pollinaria in the flower of Orchidaceae depends on the number of viscidia and of stalks to which the pollinia are attached (Szlachetko and Rutkowski 2000). There is an even number of pollinia per anther that varies from two to eight, being usually uniform within a genus and probably also within the subtribes and tribes (Freudenstein and Rasmussen 1996). However, there are exceptions: In Brachionidium the number of pollinia varies from six to eight (Stenzel 2000; Becerra 2005). With respect to the number of pollinia, several interpretations have been made. Dressler (1993) inferred a possible pattern of reduction from eight, six, four to two pollinia, being the most advanced state. However, Freudenstein and Rasmussen (1996) considered that four pollinia are a plesiomorphic condition in orchids, two pollinia are the result of the merger of the four, and the eight pollinia may be caused by the transverse or longitudinal division of the pollen sacs.

The texture of Epidendroideae pollinia varies from granular, sectile to compact. This last type represents the greatest degree of cohesion of pollen and is deposited in full within the stigma. The compact and sectile pollinia are entire or have a longitudinal, dorsi-ventral or lateral suture or groove (Rasmussen 1982; Freudenstein and Rasmussen 1996, 1997; Johnson and Edwards 2000; Chase 2009). On the contrary, the sectile pollinia are subdivided into massulae, and one pollinium could pollinate several flowers (Johnson and Edwards 2000). The granulate pollinia are present mainly in the basal genera (Hesse et al. 1989; Rothacker 2007). The pollinium is generally accompanied by the accessory structures caudicle, tegular or hamular stipe, and viscidium. These facilitate the pollinium adhesion to the body of the pollinator (Johnson and Edwards 2000; Szlachetko and Rutkowski 2000; Peter and Johnson 2006; Harder and Johnson 2008; Nieto and Damon 2008; Damon and Nieto 2012). The origin and shape of accessory structures have been discussed in some papers. The appendiculae caudicles have pollen, but in other cases the caudicles are freniculae, only composed of an elastic material (Mansfeld 1935; Dressler 1981, 1993; Freudenstein and Rasmussen 1997; Johnson and Edwards 2000; Szlachetko 2003; Peter and Johnson 2006; Szlachetko et al. 2006; Harder and Johnson 2008; Szlachetko et al. 2012). Two types of stipe have been identified, tegular or hamular. Both types originate from rostelar tissue. The tegular stipe is formed by the outer epidermis covering the rostellum. On the contrary, the hamular stipe is formed by the apical part of the rostellum when it bends towards the anther (Szlachetko and Rutkowski 2000). Eventually, the viscidium may be diffuse or detachable, composed only by glue or a more elaborated cell structure (Dressler 1986; Freudenstein and Rasmussen 1999; Rothacker 2007; Pedersen et al. 2013). To more easily understand the parts of the pollinarium, the drawing in Fig. 1 shows its characteristics.

Many anatomical studies in Epidendroideae have focused on the analysis of vegetative structures (e.g. Stern and Whitten 1999; Stern et al. 2004; Stern and Carlsward 2008; Stern 2014) and the gynostemium (Szlachetko and Rutkowski 2000; Szlachetko and Margońska 2002; Szlachetko 2003; Szlachetko and Mytnik-Ejsmont 2009). The characteristics of the pistil are useful data to characterize genera and closely related species (Veyret 1981); in the case of Vandoidea, the characters of the rostellum are useful to separate some genera (Senghas 1993; Szlachetko et al. 2012). Features such as the number of carpels, locules, ovules, and type of vascularization can provide critical information for understanding the floral evolution of the family Orchidaceae. Some authors have suggested that the gynoecium of the orchids consists of six carpels, three sterile and three fertile (Lindley 1830-1940, 1847; Saunders 1923; Arber 1925; Vermeulen 1966). More recently, Rasmussen and Johansen (2006) inferred that there are only three carpels divided into six valves, three of them sterile. In addition, Kocyan and Endress (2001) and Mosquera-Mosquera et al. (unpublished data) studied 3-carpellar pistils in Apostasia and Neuwiedia (Apostasioideae).

Most orchids have a unilocular ovary, while only a few supposedly basal groups have three locules (Reichenbach 1854; Sing-Chi 1982; Seidenfaden and Wood 1992; Freudenstein and Rasmussen 1999; Cameron 2003; Chase 
Fig. 1 Components of the Orchidaceae pollinarium, and pistil parts in transversal section

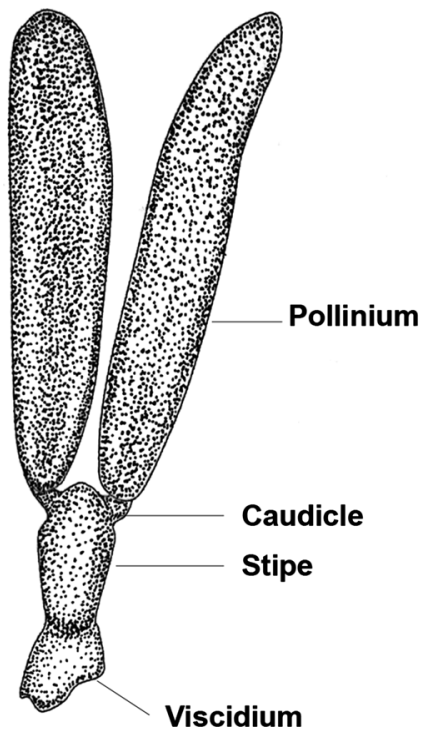

et al. 2015). The trilocular condition, a result of the postgenital product of the fusion of the septa of the ovary, has been observed in Apostasioideae (Kocyan and Endress 2001) and Cypripedioideae (Atwood 1984; Mosquera-Mosquera et al. unpublished data). In Epidendroideae this character has been found in Palmorchis-Neottieae by Veyret (1981). In this regard, Swamy (1949) inferred that the trilocular ovary gradually turns into the unilocular ovary. Epiphytic orchids often have trichomes or elaters (Cribb 1999). The intra-ovarian and endocarpic trichomes have scarcely been studied in Orchidaceae; they have only been described in Aeridiinae (Hallé 1986), some Angraecinae (Freudenstein and Rasmussen 1999), and one member of Oncidiinae Oncidium flexuosum (Mayer et al. 2011). The vascularization of the pistil is another issue incipiently discussed in Orchidaceae. The floral venation patterns have not only been used for phylogenetic problem solving but also for establishing homologies between the floral organs (Gustafson 1995; Solis and Ferrucci 2009).

The main purpose of this paper is to study and describe the variability of the pollinarium and pistil and to reconstruct the ancestral states of the pollinarium in Epidendroideae, as a contribution to help understand the role of these structures in the process of pollination and its implications in the enormous radiation of this subfamily.

\section{Materials and methods}

\section{Material}

Taking into account that the relationships within Epidendroideae tribes were much clarified by analyses of multiple DNA regions, we follow the classification proposed by
Chase et al. (2003, 2015) who recognized the larger clades as tribes and did not support the Epidendroideae "phylads" proposed by Dressler (1993). In their classification, Chase et al. (2003) rearranged some problematic genera (e.g. Thaia) and segregated three new tribes: Thaieae, Xerorchideae, and Wullschlaegelieae. In Epidendroideae, Chase et al. (2015) recognized a total of 16 tribes, 27 subtribes, and approximately 514 genera. In their phylogenetic studies, four large clades are separated: Vandeae + Podochileae + Collabieae, Cymbidieae, Malaxideae, and Epidendreae.

We have studied samples belonging to 109 genera of fourteen of the sixteen tribes of the subfamily Epidendroideae. To make a comparison, we also included genera belonging to the remaining four subfamilies of Orchidaceae (Apostasioideae, Vanilloideae, Cypripedioideae, and Orchidoideae). We studied mainly fresh material, from the collections of Roberto de Angulo Blum (Popayán, Colombia), Rafael Geovo (Istmina-Chocó, Colombia), and the Sociedad Colombiana de Orquideología "SCO" (Medellín, Colombia), and a few dried samples provided by the Herbaria CHOCO (Universidad Tecnológica del Chocó, Quibdó, Colombia), COL (Universidad Nacional de Colombia. Bogotá. Colombia D.C.), HPUJ (Universidad Pontificia Javeriana, Santafé de Bogotá, Colombia. D.C.), HUA (Universidad de Antioquia, Medellín, Colombia), and JAUM (Fundación Jardín Botánico Joaquín Antonio Uribe, Medellín, Colombia), K (Royal Botanic Gardens Kew, England, UK), LEB (Universidad de León, León, Spain), and MA (Real Jardín Botánico, Madrid, Spain), that provided us with permission required for the destructive sampling conducted. In a few cases dry specimens were used (e.g. Barbosella, Corallorhiza, Bletia, and Brassavola); the dry pollinaria were very carefully extracted to avoid damage or breakage of the structures, such as the tegula or hamulus, 
because once deformed, it is very difficult to carry out a proper examination. Some information was obtained from the literature. For example, the features of the pollinium of Thaia follow Xiang et al. (2012) who describe and draw a sectile pollinium. The vouchers of the studied taxa and the references consulted are listed in the Online Resource 1.

\section{Palynological study}

The pollinaria were extracted from the anthers and photographed with a Nikon stereomicroscope $11.25 \times$ digital camera Nikon Dxm1200. Images were captured with the software NIS-Elements F 2.20. The fresh pollinaria were dried at $60{ }^{\circ} \mathrm{C}$ for $8 \mathrm{~h}$. In all cases, pollinaria were coated with gold-palladium before examining them under a scanning electron microscope Jeol 6100 (Microscopy service of the University of León, León, Spain). The pollinarium characters were described according to the specific terminology proposed for orchids (Schill and Pfeiffer 1977; BurnsBalogh 1983; Dressler 1986; Hesse et al. 1989; Dressler 1993; Freudenstein and Rasmussen 1996, 1997, 1999; Johnson and Edwards 2000; Szlachetko and Rutkowski 2000; Szlachetko and Margońska 2002; Szlachetko 2003; Sáenz 2004; Singer et al. 2008; Szlachetko and Mytnik-Ejsmont 2009).

\section{Anatomical study}

All samples were studied at anthesis to avoid changes in tissues linked to the developmental state (for example, the hard or lignified tissues in mature and older specimens). However, in the genera, Huntleya, Peristeria, Cattleya, and Sophronitis cross sections of ovaries were made in different floral stages to observe a possible variation in the number of locules and carpels. The fresh samples were fixed in FAA (formalin-alcohol-acetic acid, 90:5:5). Dried samples were rehydrated with a descending series of alcohols $(96.5 \%$, $85 \%, 70 \%, 50 \%, 30 \%$ ), by immersion during $2 \mathrm{~h}$ in each of the first 4 and $8 \mathrm{~h}$ in the last. Afterwards, samples were washed with distilled water and finally immersed in chloral hydrate for 2 days to complete hydration and partial clarification of the tissues (Mosquera-Mosquera et al. unpublished data). Pistil cross sections were made with a Leitz 1320 freezing microtome. The obtained slices had a thickness of 5-10 $\mu \mathrm{m}$. They were observed and photographed with a fluorescence microscope Nikon Eclipse E600. The measurements were performed using the NIS-Element AR 3.1. We follow the proposals for the terminology used in anatomical descriptions by Swamy (1948), Lavarack (1971), Walker (1975), Sterling (1974, 1977, 1978), Clifford and Owens (1990), Zhang and O’Neill (1993), Stern et al. (1993), Gasser and Robinson-Beers (1993), Kocyan and Endress (2001),
Rasmussen and Johansen (2006), Tsai et al. (2008), Endress (2011), and Mayer et al. (2011).

\section{Ancestral reconstruction of characters}

The pollinarium data compiled were recovered mainly from the material studied. To analyse the morphological evolution of the Epidendroideae we selected four representative pollinia characters, previously considered taxonomically important to perform the ancestral states reconstruction (Online Resources 2, 3).

The selected characters were traced over a BI (Bayesian inference) tree resulting from the phylogenetic analyses of a matrix generated with 5256 characters of sequences of nuclear ribosomal DNA (ITS) and plastidial (matK and trnL-F) retrieved from GenBank of 97 genera of Epidendroideae and 12 genera belonging to the other four subfamilies of Orchidaceae (Online Resource 1). The sequences were aligned automatically (Geneious v.9.1 Biomatters) and subsequently verified and adjusted manually. The analysis was performed with MrBayes on XSEDE using the CYPRES (Miller et al. 2010). The resulting trees were edited with TreeGraph2 (Stöver and Müller 2010). Maximum parsimony (MP) and maximum likelihood (ML) ancestral state reconstruction analyses were performed using Mesquite (Maddison and Maddison 2014).

\section{Results}

A summary of the studied characters is provided in Online Resource 2 and illustrated in Figs. 2, 3, 4 (pollinia and pollinarium) and Figs. 5 and 6 (pistil).

\section{Variations in pollinium and pollinarium of Epidendroideae}

The pollinium of Orchidaceae is defined as the packaging of pollen in a compact, sectile, or granular unit. If the pollinium is fixed to accessory structures (caudicle, stipe, and viscidium), it is termed pollinarium. The variations in the pollinium are related to several characters: texture, number, size, orientation, and the presence of a suture or a groove. The suture varies in length and orientation in the pollinia of the subtribes Oncidiinae and Stanhopeinae. Finally, the type and number of accessory structures present important variations. Figure 2 illustrates all these variations: granular (Fig. 2a), sectile, and compact pollinia (Fig. 2b), with two, four (Fig. 2c-f), six, or eight pollinia, and pollen grains in the appendiculae caudicle (Fig. 2f) or elastic caudiclefreniculae (Fig. 2g), tegular stipe (Fig. 2h) when present, and removable or detachable (Fig. 2h) and diffuse (Fig. 2i) viscidium. 
Fig. 2 Diversity of pollinarium and pollinium and accessories structures observed in the SEM and stereomicroscope. a Granular pollinium of Epipactis hispanica. b Compact pollinium of Angraecum sesquipedale. c Juxtaposed pollinia of Cycnoches densiflorum. d Superposed pollinia Huntleya meleagris. e Full pollinarium of Oncidium povedanum. f Appendiculae caudicle of Epidendrum difforme. $\mathbf{g}$ Freniculae caudicle of Oncidium varicosum. h Tegular stipe and removable viscidium of Ada elegantula. f Diffuse viscidium of Huntleya meleagris. Scale bars: $\mathbf{a}, \mathbf{d}=1 \mathrm{~mm} ; \mathbf{b}-\mathbf{c}$, $\mathbf{e}, \mathbf{i}=500 \mu \mathrm{m} ; \mathbf{f}-\mathbf{g}=100 \mu \mathrm{m}$; $\mathbf{h}=200 \mu \mathrm{m}$. Po pollinium, $\mathrm{Su}$ suture, $C a$ caudicle, St stipe, Aca appendiculae caudicle, Fca frenicular caudicle, $V i$ viscidium, $D v i$ diffuse viscidium, $R v i$ removable viscidium
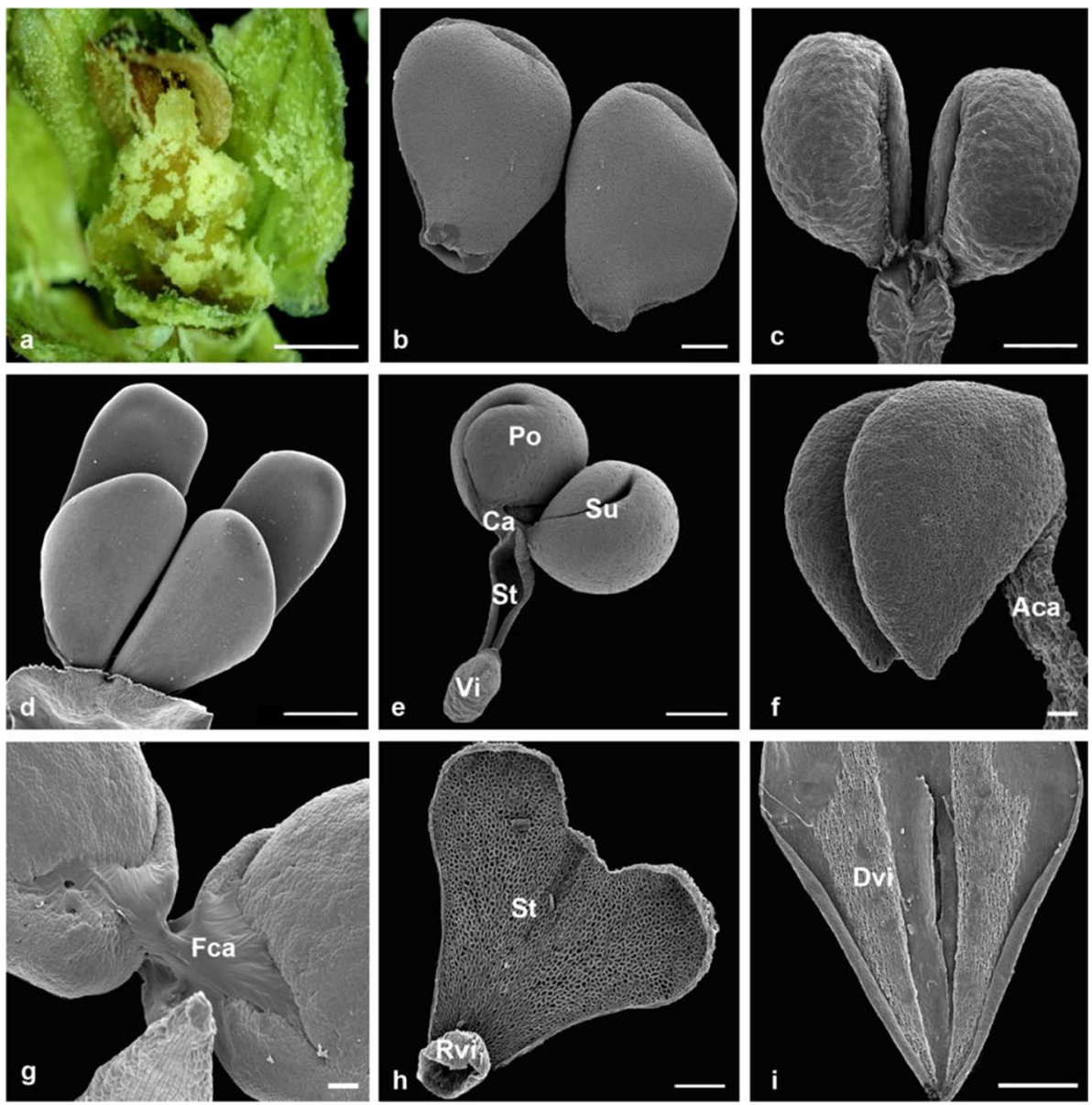

\section{Pollinium texture}

The pollinia of Epidendroideae present three different textures: granular, sectile, and compact (Fig. 2). The granular texture (Fig. 2a) was observed in members of the tribes Neottieae (e.g. Cephalanthera and Epipactis), Sobralieae (Sobralia), Arethusinae (Arundina). The sectile pollinium is present in Nervilieae (Nervilia), Tropidieae (Corymborkis and Tropidia), Wullschlaegelieae (Wullschlaegelia) and Thaieae (Thaia). Finally, the compact pollinium (Fig. 2b) is the most frequent arrangement of pollen in Epidendroideae.

\section{Pollinia number with accessories structures}

The Epidendroideae pollinarium is composed of two, four, six, or eight pollinia (Fig. 3). The pollinarium contains the accessory structures caudicle, stipe, or viscidium. In this regard, we observed that with a greater number of pollinia, the fewer number of accessory structures adhered to them. For example, pollinaria formed by six pollinia only present caudicle, whereas the pollinaria with two pollinia are formed by caudicle, stipe, and viscidium, with the exceptions of Pleurothallidinae and Laeliinae.

\section{Pollinia size}

We found notable differences in the size of pollinia within and between tribes and subtribes of Epidendroideae, from very small pollinia in Pleurothallidinae $(110 \mu \mathrm{m}$ long and $305 \mu \mathrm{m}$ wide) to the biggest size in Catasetinae (4300 $\mu \mathrm{m}$ long and $2752 \mu \mathrm{m}$ wide). Only Zygopetalinae has pollinia more or less regular in size (1320-1750 $\mu \mathrm{m}$ long and 635-952 $\mu \mathrm{m}$ wide).

\section{Pollinia orientation}

Inside the anther, the pollinia orientation is juxtaposed or superposed. In the juxtaposed pollinia-one pollinium is next to the other-(Fig. 4a-d, f, h-1). On the contrary, the superposed pollinia are located one over the other (Fig. 2e, g). The juxtaposed pollinia are the most frequent in many of the Epidendroideae subtribes, except in Coelogyninae, Maxillariinae, Zygopetalinae, and tribe Malaxideae, where they are superposed. Both types of orientation coexist in Oncidiinae; for example, if there are two pollinia the most frequent orientation is juxtaposed, but when there are four as in Caluera and Ornithocephalus, they are superposed. 

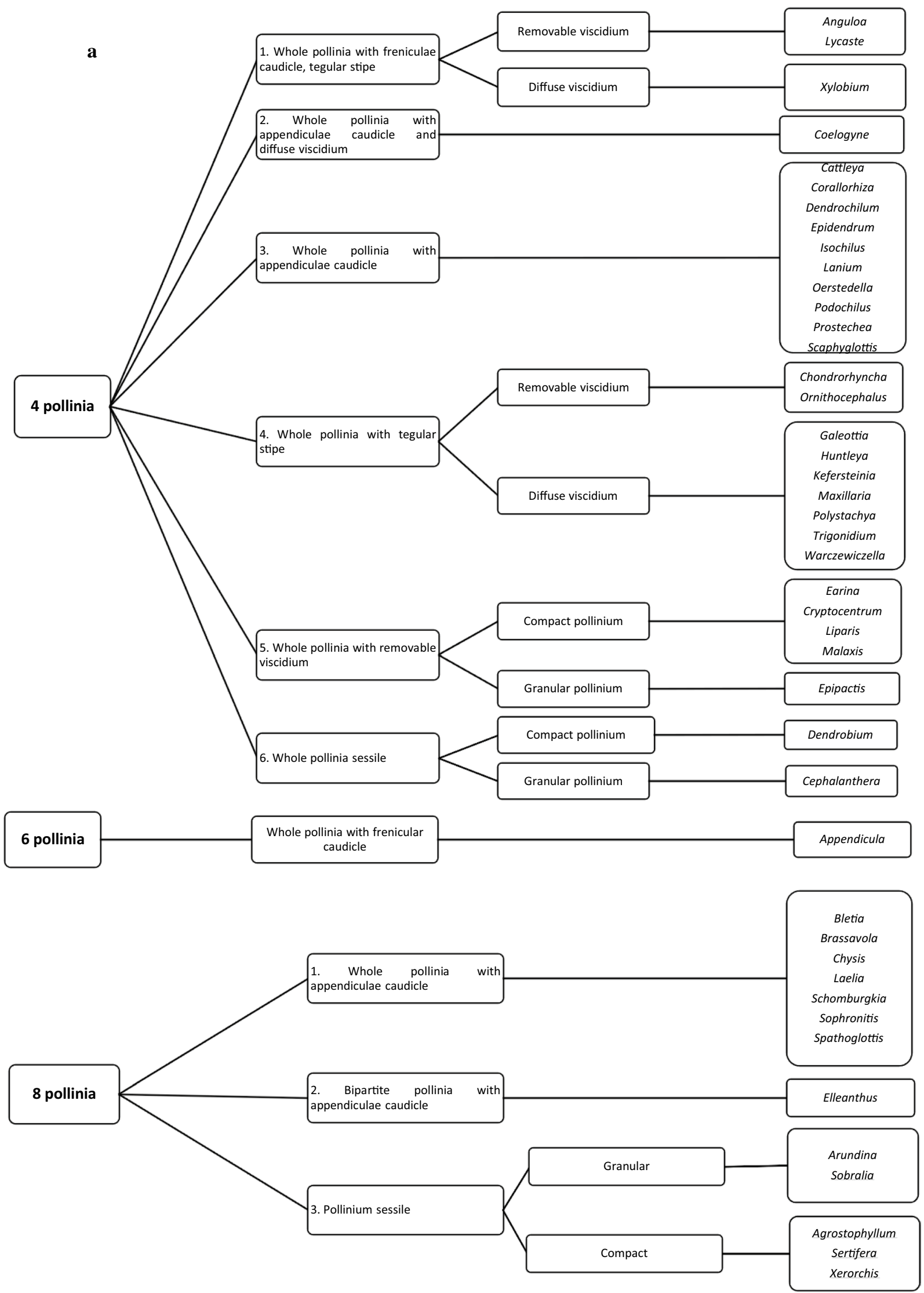

Fig. 3 Summary of pollinarium types in Epidendroideae arranged from primitive to derived types according to pollinia number 
b

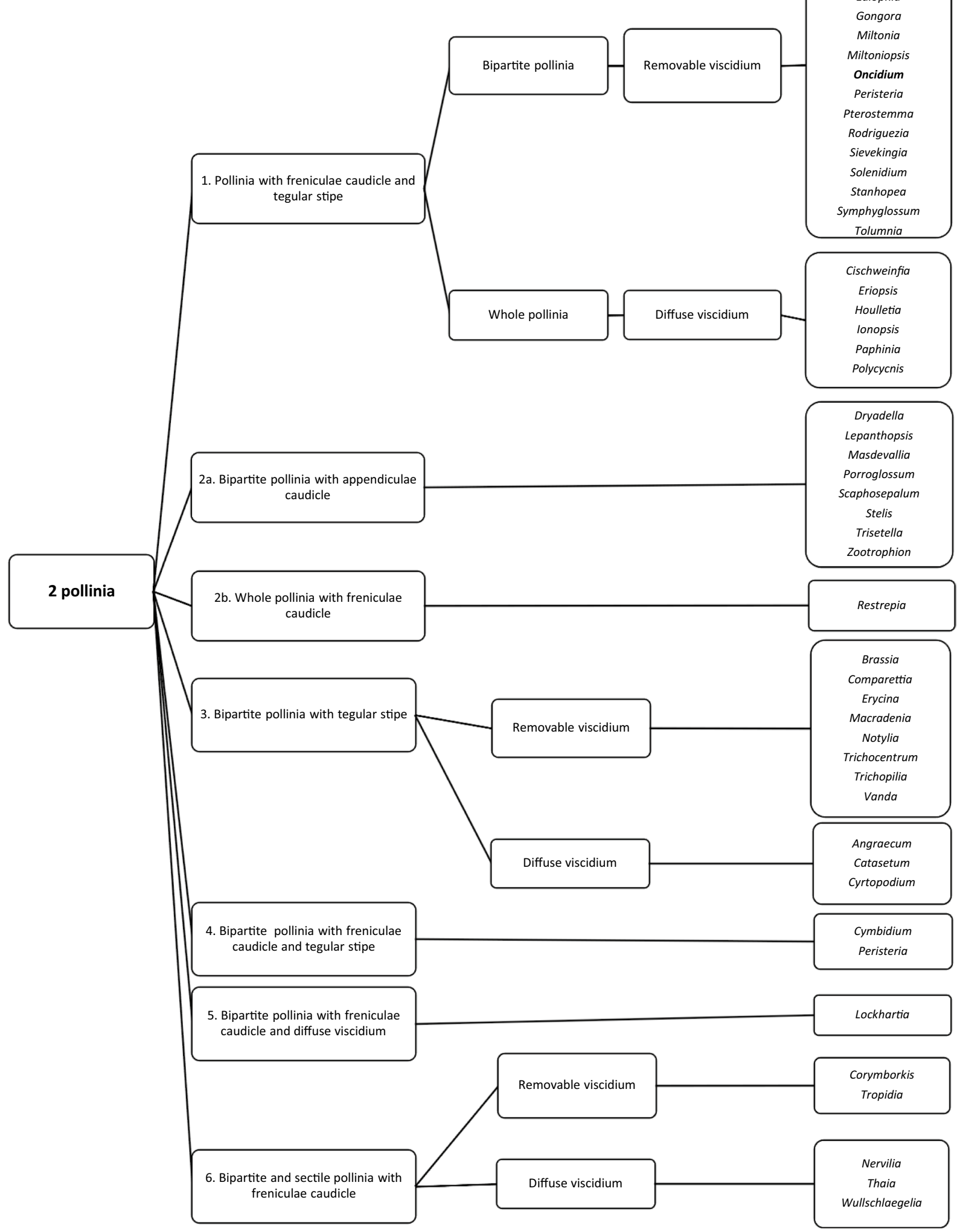

Fig. 3 (continued) 
Fig. 4 Pollinaria with two, four, and eight pollinia seen with the stereomicroscope: a Vanda coerulea, b Gongora latisepala, c Peristeria elata, d Brassia gireoudiana, e Chondrorhyncha amabilis, f Coelogyne massangeana, $\mathbf{g}$ Maxillaria cucullata, h Oerstedella wallisii, i Elleanthus myrosmatis, j Schomburgkia splendida, $\mathbf{k}$ Laelia tenebrosa, $\mathbf{l}$ Brassavola nodosa. Scale bars: $\mathbf{a}-\mathbf{c}, \mathbf{e}-\mathbf{f}$, $\mathbf{j}-\mathbf{l}=1 \mathrm{~mm} ; \mathbf{d}, \mathbf{g}-\mathbf{i}=0.5 \mathrm{~mm}$
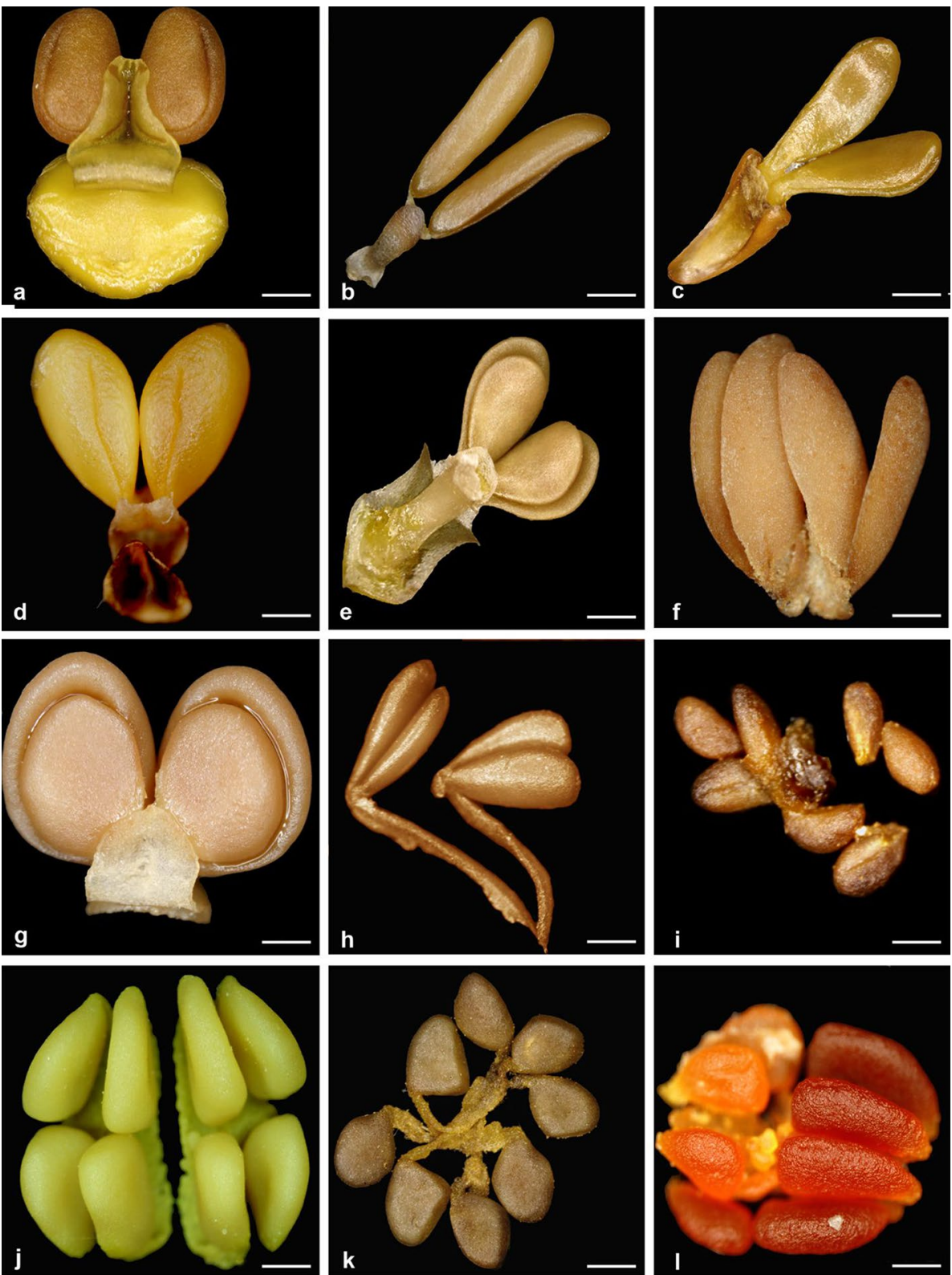

\section{Pollinia with suture}

Some pollinia in Epidendroid present a suture (Fig. 4a-d, i). It varies in its length and position in the pollinium. The pollinium with suture is typical of the tribe Cymbidieae except in the subtribes Maxillarieae and Zygopetalinae. Nevertheless, this is not exclusive to compact pollinia. It occurs in genera with sectile pollinia (Corymborkis, Tropidia, Nervilia, Thaia, and Wullschlaegelia) or pollinaria with more than two pollinia such as Elleanthus (Fig. 4i).

\section{Structural variations of the pistil in Epidendroideae}

\section{Number and arrangement of carpels}

The gynoecium is syncarpous in Epidendroideae. It is formed by three carpels divided into six valves. Three of them are placentiferous and three sterile. In addition, there are many morphological variations in size and union of carpels (Fig. 5), as we observed in the genera Cattleya, Dryadella, Masdevallia, and Stanhopea (Fig. 5b, j, k). 
Fig. 5 Pistil characters of some taxa of Epidendroideae observed with light field and fluorescence microscopes. a Cattleya quadricolor: three carpels divided into six valves (*three very reduced and sterile). b Dryadella meiracyllium: three carpels divided into six valves. c Anguloa clowesii: unilocular ovary, linear placenta. d Huntleya meleagris: unilocular ovary with elongated placenta connected in the centre of the locule. e H. meleagris: detail of the proximal part of the placenta. f Angraecum sesquipedale: detail of extension of placental tissue. g Vanda coerulea: detail of intermediate stages in the extension of placental tissue and sterile valves with intra-ovarian trichomes (IT, arrows). h Miltonia spectabilis: pistil with undifferentiated ovular tissue (UOT) surrounded by ovarian transmitting tracts (OT, arrows). i Epipactis hispanica: diffuse placenta. j Masdevallia coccinea: carpels irrigated only by ventral vascular bundles. k Stanhopea wardii: strongly vascularized carpels with ventral and lateral bundles. I Zootrophion oblongifolium: styloid crystals (Mi). Scale bars: a, $\mathbf{b}, \mathbf{j}-\mathbf{k}=500 \mu \mathrm{m}, \mathbf{c}-\mathbf{i}=200 \mu \mathrm{m}$, $\mathbf{l}=50 \mu \mathrm{m}$
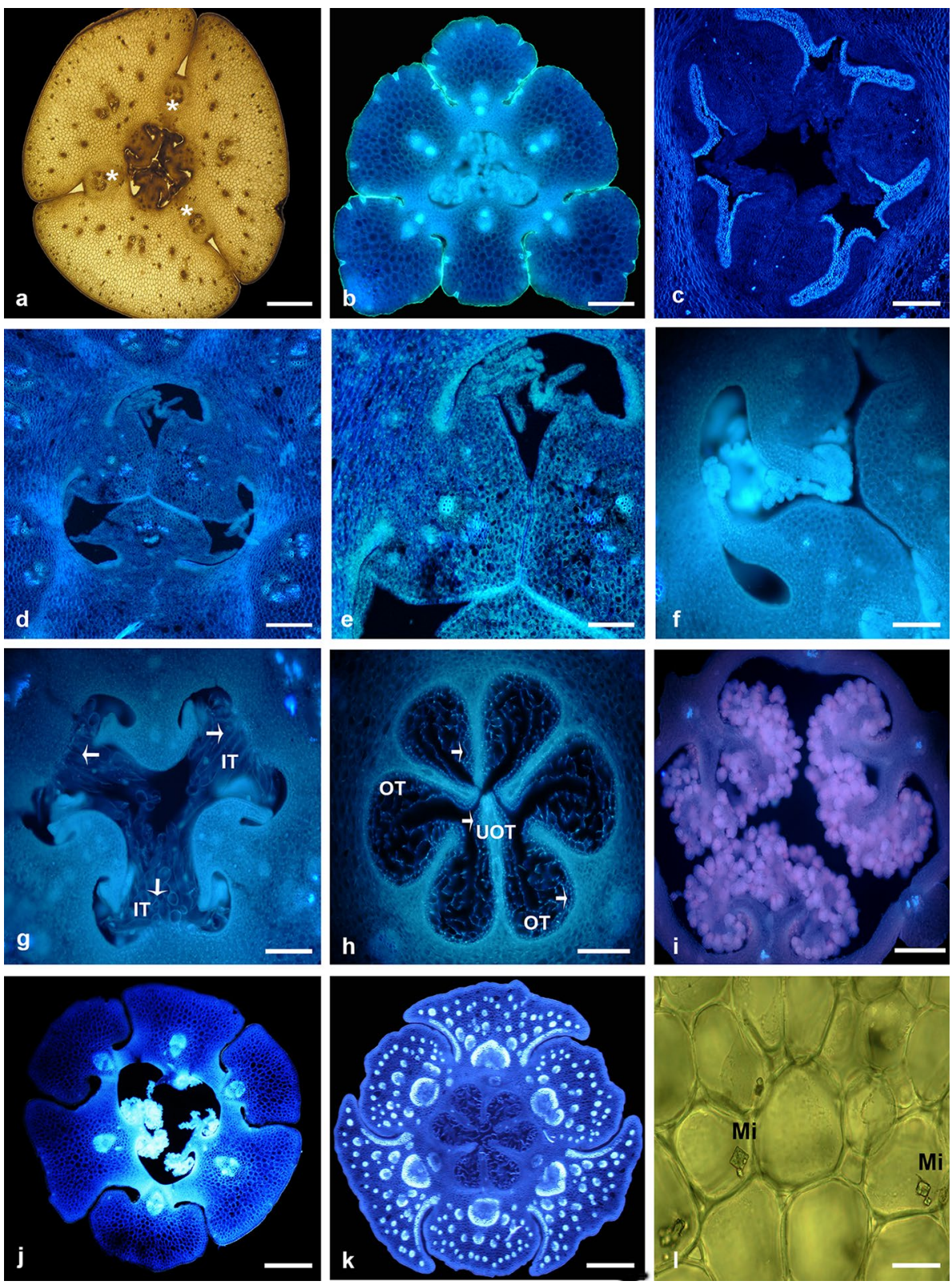

The structure of carpels in the ovary of Cattleya and Sophronitis is very different from the rest of the Epidendroideae, hindering its interpretation. Frequently, the sterile valves in this subfamily are the same size as the fertile valves, but in Cattleya (Fig. 5a) and Sophronitis, only the fertile carpels are visible. They are semi-triangular in transversal shape having abundant parenchyma, a central vascular bundle and several lateral ones. The three extremely reduced and sterile valves are hidden between the fertile ones, and the carpel is extremely reduced or little developed (see asterisks in Fig. 5a). Other Epidendroideae have the six visible but heteromorphic valves, as we observed in Dryadella, Masdevallia, and Stanhopea (Fig. 5b, j, k). The carpels have different degrees of separation: There are pistils connate only at the base, or rather connate between the sides, as occurs in Zygopetalinae. In these cases, they differ completely from the carpel walls. However, there is another condition in which the walls of the carpels are fused almost completely, i.e. in Epipactis, Lockhartia, Ornithocephalus, and Erycina.

\section{Locule number, placentation, and disposition of ovules}

In Epidendroideae the pistil is clearly unilocular with parietal placentation, but for example, in Cattleya (Fig. 5a), Laelia, Huntleya (Fig. 5d), Peristeria, Sophronitis, Angraecum (Fig. 5f), and Vanda (Fig. 5g), the placentae are projected towards the centre of the locule. Only in Huntleya (Fig. 5d, 
Fig. 6 Pistil characters. a Stanhopea wardii: orthotropic ovule. b Epipactis hispanica: anatropous ovules. c Spathoglottis plicata: trichomes on the outer wall of the ovary. $\mathbf{d}$ Arundina graminifolia: ventral vascular bundles. e Trigonidium egertonianum: dorsal and lateral vascular bundles. f Cryptocentrum latifolium: carpellar valves with sclerenchyma. Scale bars: $\mathbf{a}-\mathbf{d}=500 \mu \mathrm{m}, \mathbf{b}-\mathbf{e}=200 \mu \mathrm{m}$, $\mathbf{f}=100 \mu \mathrm{m}, \mathbf{c}=50 \mu \mathrm{m} . V B$ ventral bundle, $D B$ dorsal bundle, $L B$ lateral bundle
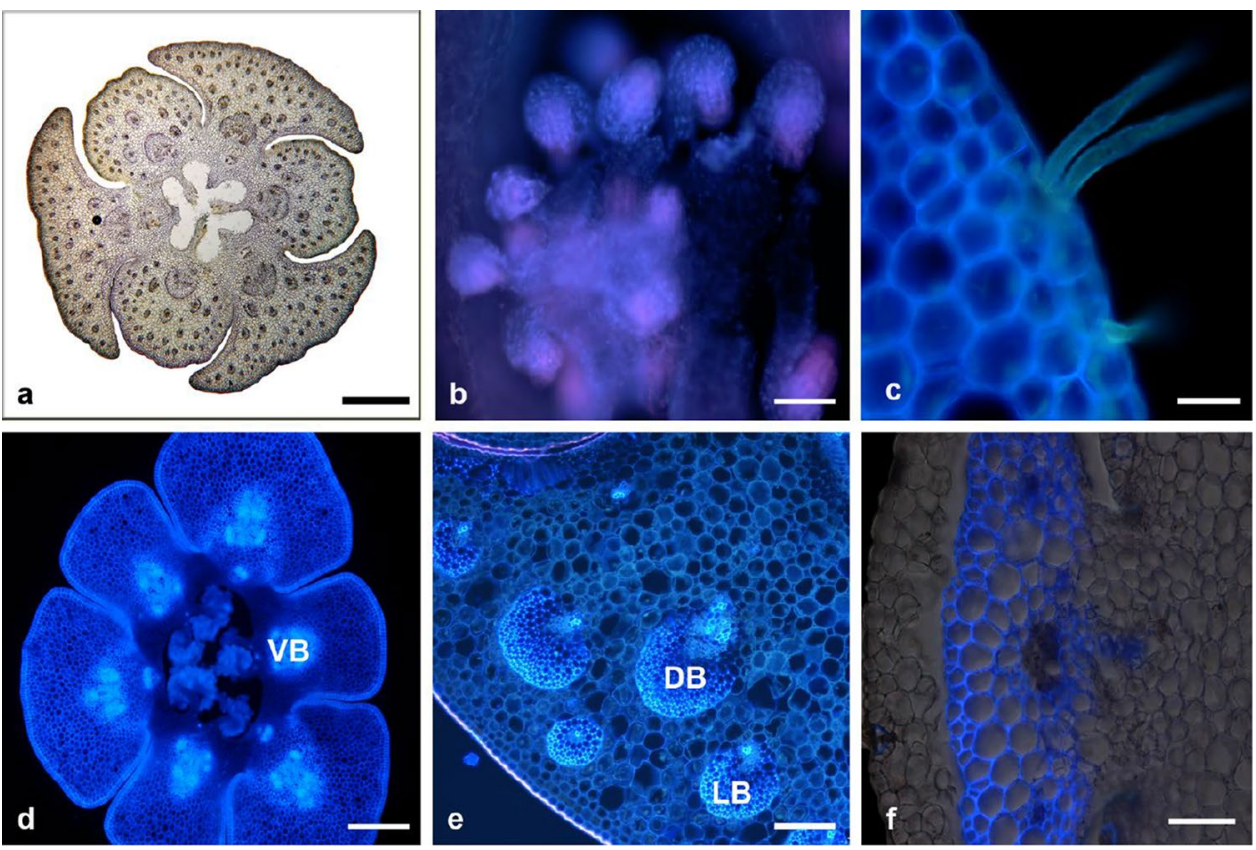

e) and Peristeria the placentas are deeply intruding towards the centre of the locules, and make contact, but do not fuse, although in the middle part of the ovary they appear to have three locules, but in the basal transversal sections, the separation is more evident. Therefore, in both cases the placentation is parietal and the ovary unilocular.

The parietal placentation in Epidendroideae occurs in two ways: The most frequent is the linear placenta having one or two longitudinal rows of ovules along the fertile part of the ovary (Fig. 5a, c). The second is the diffuse placenta, as a result of the presence of several ovules dispersed in a portion of the placenta from each carpel along the ovary, as observed in some genera such as Arundina, Epipactis (Fig. 4i), Corallorhiza, Masdevallia (Fig. 4j), and Spathoglottis. Most of the ovules studied were poorly differentiated.

In this study, we report intra-ovarian trichomes in the pistils of some genera of Epidendroideae. The intra-ovarian trichomes were observed in the sterile valves. They are located in the mid-ovary region of Vanda (Fig. 5g). The outer surface of the ovary is usually glabrous in almost all samples studied, rarely pubescent with glandular trichomes as in Scaphosepalum, Stelis, Trisetella, and Zootrophion or with multicellular multiseriate trichomes in Ornithocephalus and unicellular uniseriate trichomes in Spathoglottis (Fig. 6c).

\section{Venation pattern}

There are three types of vascular bundles in the pistil of the Epidendroideae: concentric perixylematic (Trigonidium, Cryptocentrum, Paphinia, Stanhopea, Brassia, Miltonia, Oncidium, and Isochilus), concentric periphloematic (Maxillaria, Trigonidium, and Sievekingia), and collateral closed.
The vascular tissue of each carpel could be formed by ventral, ventral and dorsal, or dorsal, ventral and lateral vascular bundles. In each carpel, the lateral vascular bundles are a result of the branching of the dorsal vascular bundles of the carpel wall. These are smaller than the dorsal and ventral ones. Most of the studied species (77\%) have little-vascularized pistils with only ventral vascular bundles (Figs. 5b, j, 6d); the remaining 23\% have ventral, dorsal, and/or lateral vascular bundles (Figs. 5a, k, 6e). This is the case of Epidendrum, Schomburgkia, Sophronitis (Laeliinae), Catasetum and Cycnoches (Catasetinae), Aspasia and Trichocentrum (Oncidiinae), Acineta, Houlletia, Paphinia, Sievekingia and Stanhopea (Stanhopeinae), Peristeria (Coeliopsidinae), Huntleya (Zygopetalinae), Anguloa, Lycaste, Trigonidium (Fig. 6e), Maxillaria (Maxillariinae), and Dendrobium (Dendrobiinae).

\section{Structure and composition of the parenchyma of the carpel}

The fundamental tissue of the carpels in most of the taxa is the parenchyma, except in Cryptocentrum (Fig. 6f), Stanhopea, Isochilus, and Angraecum, that is additionally composed by sclerenchyma. It is clearly visible under ultraviolet light.

Mineral inclusions, such as raphides and druses, were found in the parenchyma in Cymbidium, Trigonidium, Acineta, Aspasia, Brassia, Porroglossum and styloid in Zootrophion (Fig. 51), Spathoglottis, and Cattleya. Crystals of flavonoids were observed in the parenchyma of the yellow or brown pistil that makes the observation of the carpel tissues difficult in Cyrtochilum, Galeottia, and Maxillaria. 


\section{Reconstruction of ancestral state characters}

The combined nuclear and plastid alignment was $5256 \mathrm{bp}$ in length. The Bayesian analyses recovered phylogenies not conflicting with the currently accepted one, with the exception of the tribes Neottieae, Sobralieae, Wullschlaegelieae, Xerorchideae, and Tropidieae, appearing in unresolved and low supported clades. Figure 7 shows the Bayesian majorityrule consensus tree with most clades having maximum support and, all the tribes monophyletic except Arethuseae and Epidendreae which are polyphyletic.

A total of 57 pollinaria and carpel characters were studied. Fourteen of them-six related to the pollinaria and eight to the carpel-were polymorphic and showed several changes. Some states arose independently twice or many more times. Such is the case of the number of pollinia, for which the ancestral states reconstruction shows eight to eleven independent origins or the case of juxtaposed pollinia with at least eleven independent origins (Fig. 5a-d).

Transformations including reversions were observed in pollinium texture (at least 6 times), a number of pollinia (13 times), pollinia with suture (twice), and pollinia orientation (5 times).

The reconstruction of the character states does not support an unequivocal hypothesis for all the traits for the most recent common ancestor (MRCA) of Epidendroideae (Online Resource 4) but suggested the most parsimonious states. In summary, Epidendroideae MRCA have pollinarium completely formed by pollinium, caudicle, stipe and viscidium $(\mathrm{ML}=0.9875)$, with four $(\mathrm{ML}=0.5880)$ granular $(\mathrm{ML}=0.6656)$ pollinia, without suture $(\mathrm{ML}=0.9928)$, and juxtaposed $(\mathrm{ML}=0.9904)$.

\section{Discussion}

Although the pollinarium and pistil characters have been widely studied in the family, a detailed study of the structures composing the pollinarium and their different states remains a necessity. Most of the references on this subject (e.g. Dressler and Dodson 1960; Schill and Pfeiffer 1977; Dressler 1981, 1993; Rasmussen 1982; Blackman and Yeung 1983; Burns-Balogh and Funk 1986; Kurzweil 1998; Freudenstein and Rasmussen 1996, 1997; Johnson and Edwards 2000; Rasmussen and Johansen 2006; Singer et al. 2008; Pedersen et al. 2013; Kant et al. 2013; Freudenstein and Chase 2015) do not show detailed images and/or schemes relating to types, shapes, and organization of the accessory structures of the pollinarium. A detailed study in a large group, such as Epidendroideae, allows better discrimination and interpretation of their evolution, affinities, origins, and possible functions. Our study corroborated the great variability in the Epidendroideae highlighted previously by several authors (Freudenstein and Rasmussen 1999; Szlachetko and Margońska 2002; Szlachetko 2003; Cameron 2003; Rasmussen and Johansen 2006; Singer et al. 2008; Nieto and Damon 2008; Szlachetko and Mytnik-Ejsmont 2009; Damon and Nieto 2012). Most of the characters are very variable within tribes and subtribes. The results of the ancestral states reconstruction highlighted this.

On the other hand, the main gynostemium traits were used to perform classifications, but there is very little information about structure and ontogeny (formation and types) of ovules. Therefore, studies like this one will always be a contribution, because knowledge about the states of the characters of the pollinarium and pistil allows a better understanding of the great variability of the subfamily Epidendroideae. It is especially important to work with fresh material that permits a better visualization and interpretation of the morphology, avoiding possible errors derived from the deterioration of the most fragile structures.

\section{Pollinarium}

The reconstruction of the ancestral character states in Epidendroideae with maximum parsimony and maximum likelihood suggested a MRCA of the Epidendroideae, the complete pollinarium, with granulate pollinium, caudicle, tegular stipe, and viscidium. In resolving the most parsimonious ancestral character state when the analyses excluded or included representatives of other subfamilies (results not shown), some results vary. This could be related to the many changes that have occurred in the characters over time, probably caused by the strategies of dispersal of the pollinium and the pollinator type. The tribes that still preserve full pollinarium are Epidendreae (Calypsoinae) and Cymbidieae (Catasetinae, Coeliopsidinae, Eulophiinae, Eriopsidinae, Maxillariinae, Oncidiinae and Stanhopeinae). There are many similarities in the pollinarium of Oncidiinae and Aeridinae; both subtribes share the number of pollinia (two or four), the existence of a suture (in the double type), the short and irregular freniculae caudicle, and tegular stipe. The exception is the viscidium, which is very similar in almost all Oncidiinae (removable viscidium, shaped platform), but highly diversified in Aeridinae. The nature of the pollinarium is a principal factor in understanding the evolution of the family Orchidaceae. It has been used as a relevant character in the classification and species identification because its features are taxonomically informative (Dressler 1986; Singer and Koehler 2004; Ramírez et al. 2007). However, some authors suggested parallel or convergent trends in pollinarium/pollinium morphology in the orchid groups (Williams 1970; Stenzel 2000; Dathe and Dietrich 2006) and that pollinarium types must have evolved several times independently (Singer and Koehler 2004; Dathe and Dietrich 2006). 


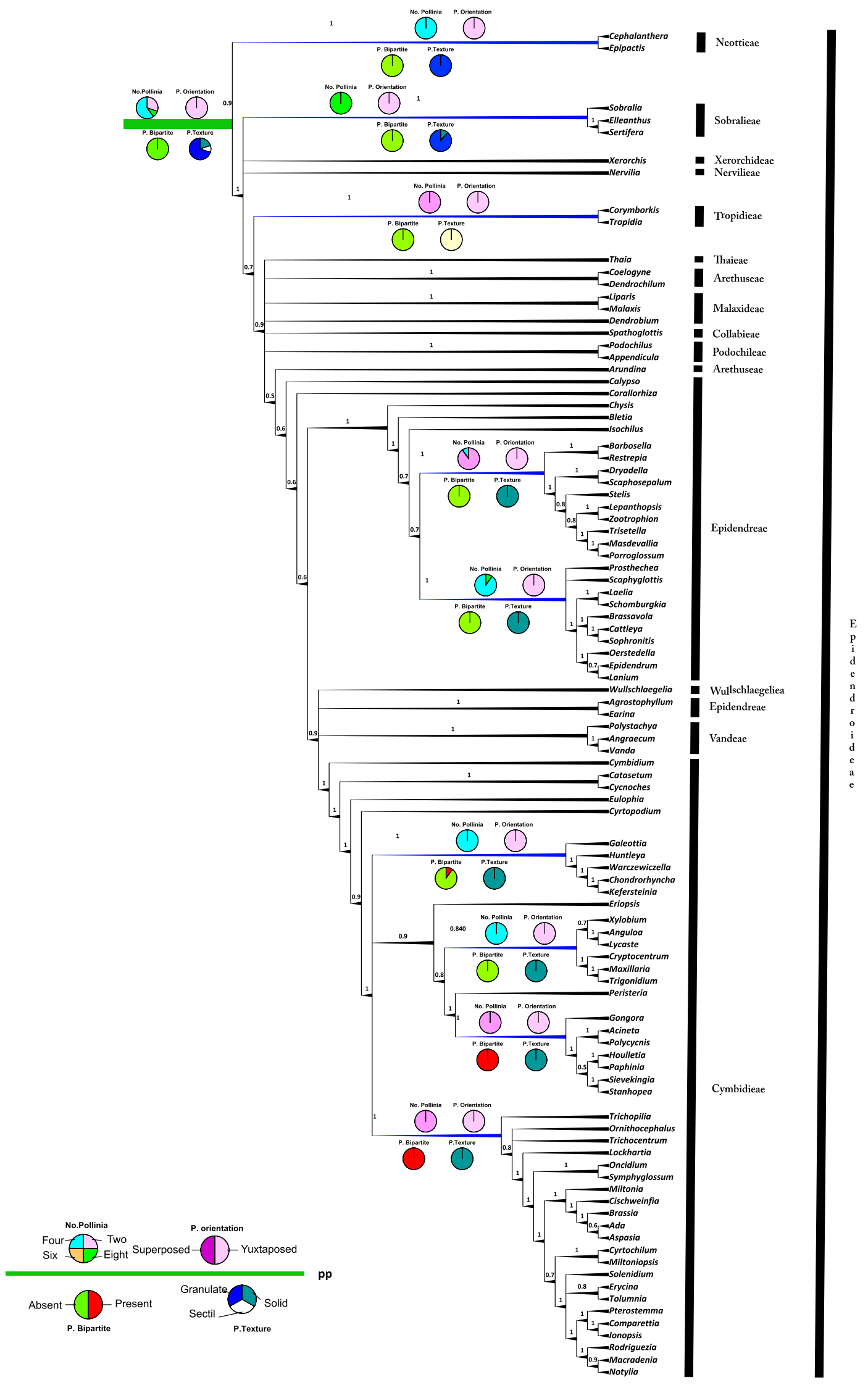


4Fig. 7 Bayesian tree obtained from the analysis of the combined data set (ITS, matK, trnL-F). The cladogram includes outgroups and shows the relationships among Epidendroideae. The tribes and subtribes classification follows Chase et al. (2015) and Freudenstein and Chase (2015). The values above branches are Bayesian posterior probabilities (BPP). The pie charts representing the ML probability of the states for the selected characters. The interpretation of each character and colour appears in the legend below the tree

The compaction of pollen in the pollinia in Epidendroideae may probably be caused by the modification of the strategies of pollen dispersal, in comparison with the usual dispersal known in other plants. It could be due to the fact that the masses of pollen in variable quantity and weight turned into ballast for pollinators whose body structure would not support such dimensions (because of pollinia size and weight). Probably, as part of the evolution in the family, the attached or accessory structures of the pollinia (caudicle, stipe, and viscidium) were formed to facilitate transport and together with the pollinia, constitute the pollinarium. Previously, other studies have mentioned that the caudicle, stipe, and viscidium attached to pollinium have different origins (Dressler 1993; Johnson and Edwards 2000; Singer and Koehler 2004). It has also been inferred that the association of the accessory structures with the pollinium is closely related to the strategy of transfer of pollen (Dressler 1986; Pacini and Hesse 2002; Singer and Koehler 2004) and that the structure and function of the pollinarium cannot be studied isolated from other structural modifications which occurred during the evolution in Orchidaceae (Dressler 1986; Johnson and Edwards 2000).

The Epidendroid caudicles are of two types: (1) Freniculae, elastic and sticky, that are considered to be the apomorphic state (Freudenstein and Rasmussen 1997). This occurs in Cymbidiinae, Catasetinae, Maxillariinae, Stanhopeinae, Coeliopsidinae, Oncidiinae and Aeridinae. (2) Appendiculae caudicle composed by elastoviscin and pollen occurs in Bletiinae, Collabiinae, Coelogyninae, Sobralieae, Laeliinae, and Pleurothallidinae. Both types were proposed by Mansfeld (1935) and accepted by Freudenstein and Rasmussen (1997). The two types vary in length; the longest occurs in some Bletiinae, Collabieae, Sobralieae, and Laeliinae, which coincide with the absence of the rest of the accessory structures. The appendiculae caudicles are considered as an extension of the pollinia (Freudenstein and Rasmussen 1997). Probably the absence of viscidium, for which the main function is to stick the pollinium to the pollinator's body, losing this function, wherein the caudicle then functions as the breaking point to facilitate deposition of the pollinia on the stigma (Johnson and Edwards 2000). There is no relationship between the size and the number of the pollinia and their evolution. This is evident in some Laeliinae (Brassavola, Laelia, Schomburgkia, and Sophronitis) having eight large pollinia. One would expect that the more the pollinia, the smaller they will be. Their reduction would make transport of the pollinarium by the pollinating vectors easier and allows us to hypothesize that probably because of the difficulty in transporting the pollinarium of these taxa, it has a completely different morphology from the rest: Their joined caudicles form a mat with the pollinia attached to both ends (Fig. 2a). A study in Laelia rubescens revealed that only four of the eight pollinia are attached as a unit through the column of viscous material. They are transported by the animal vector to rather large receptive flowers, while still forming a package of four large pollinia relative to the stigmatic surface, making it difficult and mechanically unlikely that pollinia from different sources may be deposited on the stigma (Trapnell and Hamrick 2006).

The stipe of Epidendroideae is usually individual and tegular, but is variable in length and shape. The pollinarium is hamular only in the Tropidieae. Both types, tegular and hamular pollinia, originate from the rostellum (Szlachetko and Rutkowski 2000). The last accessory structure composing the pollinaria is the viscidium, that in Epidendroideae can be diffuse (Kurzweil 1988; Freudenstein and Rasmussen 1997; Rothacker 2007; Pedersen et al. 2013) or detachable (Kurzweil 1988; Freudenstein 1994; Freudenstein and Rasmussen 1997; Rothacker 2007) and plays a very important role in the dispersion of the pollinarium. Some authors highlight the functional importance of the stipe and viscidium in the pollination process (Dressler 1981, 1993). The stipe, by its length, facilitates the approach of the pollinia to the stigma (Hidayat et al. 2006), and the viscidium, by its viscous and sticky consistency, adheres the pollinium to the body of the pollinator (Johnson and Edwards 2000). However, it was observed in this study that in some cases in the absence of both structures, the caudicle assumes the function of adherence of the pollinia to the pollinator, as occurs in Laeliinae (Oerstedella, Prosthechea, Scaphyglottis, Brassavola, Sophronitis, and Laelia). Laelia is a good example because most of them lack viscidium and its role is played by the caudicle. The much better sample is Pleurothallidinae because most members lack viscidium and its role is played by the caudicle. Finally, some members of Arethusinae (Arundina) and Dendrobiinae (Dendrobium) studied have sessile pollinia.

As expected, the reconstruction of ancestral states in the subfamily suggested for the MRCA of Epidendroideae pollinium texture that the granulate state is the most parsimonious. Nevertheless, a detailed study of the whole family (Mosquera-Mosquera et al. unpublished data) revealed that the pollinia texture has also changed over time in different directions. In this study, the granular state (Fig. 7) is only observed in basal tribes and subtribes belonging to Epidendroideae (Neottieae, Sobralieae, Arethusinae, Xerorchideae, and Agrostophyllinae) agreeing with previous authors (Dressler 1981; Hesse et al. 1989; Rothacker 2007; 
Chase et al. 2015). In Orchidaceae, only Neuwiedia and Apostasia belonging to the subfamily Apostasioideae possess powdery pollen not forming pollinia and without elastoviscin. Therefore, the occurrence of the granular pollinia with easily friable tetrads in Epidendroideae indicates that very little elastoviscin is present inside the pollinium reducing the cohesion of the tetrad, this condition being very similar to that of members of Apostasioideae (Dressler 1993; Mosquera-Mosquera et al. unpublished data).

As an intermediate condition, the sectile pollinia (Fig. 7) with the pollen organized in massulae occurs in Nervilieae, Tropidieae, Wullschlaegelieae, and Thaieae. Sectile pollinia are present in about half of the Orchidoideae species and are characteristic of the tribe Orchideae and subtribe Goodyerinae (Dressler 1993; Chase et al. 2003; Ramírez et al. 2007). It is also characteristic in the Epidendroideae subtribes Gastrodiinae, Epipogiinae, Nerviliinae, Arethusinae, Thelasiinae and Laeliinae (Freudenstein and Rasmussen 1997), Neottieae (Rothacker 2007) and Tropidieae (Singer et al. 2008). In relation to this state, Freudenstein and Rasmussen (1997) recognize two states in the whole family that they termed Orchidoid and Epidendroid. The advantage of the sectile pollinia is that a single pollinium can pollinate several flowers (Freudenstein and Rasmussen 1997; Johnson and Edwards 2000; Pacini and Hesse 2002; Harder and Johnson 2008).

Finally, most of the taxa studied show a compact or hard pollinium (Fig. 7), very common in Epidendroideae, representing the highest degree of cohesion of the pollen that is deposited as a unit on the stigma (Harder and Johnson 2008). The presence of a hard pollinium was a very important innovation for radiation of the subfamily which became the most diverse, successful and widely distributed within Orchidaceae as previously suggested by Dressler (1993). The sectile and hard pollinia seem to be apomorphic within Orchidaceae (Freudenstein and Rasmussen 1997). The sectile pollinia arose at least four or five times in the evolution of the family (Burns-Balogh and Funk 1986; Dressler 1993; Pansarin and Estanislau do Amaral 2008), particularly in Epidendroideae.

Within the Epidendroideae, the diversity of the pollen texture is such that this subfamily presents all types reported for the Orchidaceae. It seems that texture is the result of the gradual aggregation of pollen (Harder and Johnson 2008). In this process, elastoviscin has played an important role allowing the existence of different dispersion units, from monads to tetrads (Pacini and Hesse 2002), and soft, sectile, or hard pollinia (Dressler 1986; Johnson and Edwards 2000). The pollen in monads, found in the most basally diverging orchid genera, belonging to Apostasioideae is the primitive condition, but it has evolved several times in the orchid family (Dressler 1993; Cameron et al. 1999; Pansarin and Estanislau do Amaral 2008). Only Apostasioideae lacks this viscous and sticky substance, and the pollen is dispersed individually (Mosquera-Mosquera et al. unpublished data). The aggregation of the pollen in angiosperms has happened at least 39 times and independently; we think that the abovementioned changes improve the efficiency in the process of dispersion of the pollen (Harder and Johnson 2008).

There is also much diversity in the number of pollinia in Epidendroideae (Fig. 7). Although parsimony analysis does not define which of the states (two, four, six, or eight) is the most parsimonious for the MRCA of the subfamily, the four pollinia reached the highest value $(0.5880)$ in ML analyses. Therefore, this analysis would support the suppositions to interpret this character (Freudenstein and Rasmussen 1996). We recognized four types in the subfamily. The plesiomorphic state is the presence of four pollinia (Rasmussen 1986; Rothacker 2007). It occurs in Maxillariinae, Oncidiinae, Laeliinae, Pleurothallidinae, Zygopetalinae, Calypsoinae, Neottieae, Ponerinae, Agrostophyllinae, Podochileae, Coelogyninae, Polystachyinae, Malaxideae, and Dendrobiinae. The presence of six pollinia was observed in this study only in the genus Appendicula (Podochileae), besides being a rare character state in the family. The sectile texture corresponds to an intermediate state, not only in the number of pollinia but also in the trend to compaction of the pollen in Orchidaceae. It is interpreted that the compaction of the pollen has evolved from granular to sectile and then to compact (Dressler 1986; Freudenstein and Rasmussen 1996, 1997; Harder and Johnson 2008). Six pollinia have already been mentioned in the genus Appendicula (Keng et al. 1998) and for two Pleurothallidinae: Chamelophyton and Brachionidium (Stenzel 2000). The third case originated by the division of the 4 pollinia resulting in 8 (Freudenstein and Rasmussen 1996), as we observed in some members of Agrostophyllinae, Collabieae, Bletiinae, Sobralieae, Laeliinae, Arethusinae (e.g. Arundina (Szlatchetko and Margonska 2002), Xerorchideae and Podochileae. The last one, contrary to the previous one, occurred after the reduction from four to two pollinia or the fusion of the initial four pollinia. This is the most frequent case in most taxa of Epidendroideae. Subtribes having this state are Oncidiinae, Catasetinae, Cyrtopodiinae, Stanhopeinae, Eulophiinae, Nervilieae, Thaieae, Calypsoinae, Wullschlaegelieae, Tropidieae, Coeliopsidinae, Cymbidiinae, Pleurothallidinae, Eriopsidinae, Aeridinae, and Angraecinae. This change in the number of pollinia occurred especially in five subtribes with different trends, in Aeridinae, Oncidiinae, and Pleurothallidinae (reduction from 4 to 2), Agrostophyllinae and Laeliinae (a division from 4 to 8 ). A hypothetical development model of the pollinia number revealed that the shape and type of pollinia are produced by the fusion or the septation of meristematic regions in the anther tissue in the subfamily Epidendroideae. The meristem septation produces four or eight pollinia per anther, while the lack of septation resulted 
only in two pollinia per anther (Freudenstein and Rasmussen 1996). The anther formed by four pollinia seems to be primitive in the family, and the anthers with two or eight pollinia derived from them (Freudenstein and Rasmussen 1996; Cameron et al. 1999). These changes in the number of pollinia disagree with the hypothesis of a reduction pattern from eight to six, four, or two pollinia (Dressler 1993) in many groups of Epidendroideae.

Undoubtedly, there is a relationship between the number and orientation of pollinia, with some exceptions (e.g. Dendrobium and Schomburgkia). In most cases, there are four superposed pollinia, whereas in the case of two, six, or eight pollinia, they are juxtaposed, although in another study two pollinia were treated as superposed (Freudenstein and Chase 2015). A differential overgrowth of the thecae and the flattening of the anthers (by a lack of full reorientation of the juxtaposed thecae) give rise to the superposed pollinia (Freudenstein and Rasmussen 1996; Freudenstein et al. 2002; Freudenstein and Chase 2015). The subtribes Oncidiinae, Pleurothallidinae, and Aeridinae have two or four pollinia when they are double and are juxtaposed. These changes of orientation have happened in Epidendroideae on many occasions from the most basal taxa to the most recent (Fig. 7). The most parsimonious state for this character is the pollinia juxtaposed.

Freudenstein and Chase (2015) treated the double pollinia as superposed even in the cases the pollinium have a cleft or a bilobed appearance, and suggested would be an evidence of a partition that have been lost or are still being developed. It was also observed in some double pollinia studied in this research and occurred mainly in the subtribes Stanhopeinae and Oncidiinae. The presence of a suture that can vary in length and location in the pollinium, and contrary to that proposed by Freudenstein and Chase (2015), are pollinia juxtaposed because they are arranged in the theca next to each other.

The orientation of the pollinium is a condition widely related to the rotation of the thecae and the anther dehiscence (Kurzweil 1987a, b; Dressler 1993; Freudenstein and Rasmussen 1996; Freudenstein et al. 2002), associating them this way: latrorse/superposed, introrse/juxtaposed. Studies on the anther ontogeny showed that the plesiomorphic state is the introrse anthers with juxtaposed pollinia and there have been several derived states; nevertheless, the Vandeae tribe that has latrorse anthers and superposed pollinia is believed to have experienced little or no reorientation. Therefore, it is likely that the current pollinia orientation states are due to heterochronic changes in the anther (Freudenstein et al. 2002).

The most parsimonious state for the MRCA of Epidendroideae is the entire pollinium (Fig. 7) without suture $(M L=0.9929)$. Therefore, the presence of a suture in the pollinium must be considered apomorphic as it is present in most of the double pollinium. (It is the advanced/apomorphic state.) The suture is present only in a few groups and has variations in length and location in the pollinium of the subtribes Angraecinae, Catasetinae, Eulophiinae, Cyrtopodiinae, Maxillarinae (Cryptocentrum sensu Chase et al. 2003), Coeliopsidinae, Stanhopeinae and Oncidiinae and the tribe Sobralieae. Probably, one of the persistent signs, which allow inferences about the reduction of the pollinium, is the presence of the suture. That is not exclusive to the double pollinia, as it was also observed in the four pollinia in Cryptocentrum and eight pollinia of Elleanthus (Sobralieae). In the pollinia, the suture is the result of the union of the pollen content of two cores in a late stage of ontogeny; therefore, it should be considered as a different state (Freudenstein and Rasmussen 1996).

\section{Pistil}

Unlike the pollen, the pistil in the subfamily Epidendroideae has very little variation. It is unilocular, but in Huntleya (Zygopetalinae) and Peristeria (Coeliopsidinae), the pistil appears to be trilocular because the tissue of the placenta intrudes and makes contact in the centre of the locule creating three false locules. In the literature about Orchidaceae, one locule has been reported for Epidendroideae and three for Apostasioideae and Cypripedioideae (Garay 1960; Atwood 1984; Freudenstein and Rasmussen 1999; Cameron 2003). The last is the plesiomorphic state in the family. The same occurs in taxa belonging to families related to the Orchidaceae-e.g. Hypoxidaceae (Rudall and Bateman 2002; Kocyan 2007; Kocyan et al. 2011). However, some taxa such as Cattleya, Laelia, Sophronitis, Scaphyglottis (Laeliinae), Vanda (Aeridinae), and Angraecum (Angraecinae) have an extension of placental tissue, suggesting a hypothetical intermediate state. In a phylogenetic context, the further retraction of the placenta to form the unilocular ovary has occurred at least four times in orchids (Cameron 2003).

In Orchidaceae, non-fertilized flowers have ovules with poorly differentiated tissues (Sagawa and Israel 1964; Zhang and O'Neill 1993; Li et al. 2016). This was verified in most of the samples of Epidendroideae studied. Only two genera present well-differentiated ovules. One is Stanhopea, having primordial ovules presenting an erect position and differentiated teguments clearly bitegmic in the initial stages (Fig. 6a). The second is Epipactis, having an anatropous ovule (Fig. 6b). It has been asserted that before the integuments are differentiated, the curvature of the apex row cells occurs in the primordial anatropous or campylotropous ovules (Endress 2011). It defines the location of the chalaza and the micropyle position. However, more evidence is required to consider it as an orthotropic ovule given that 
there are no references to the existence of this type in the Orchidaceae family.

Orchidaceae belongs to the group of angiosperm families with larger numbers of ovules, which incidentally coincides with the presence of pollinia that can bind between 5000 and $4,000,000$ pollen grains (Schill et al. 1992). There are two ways to interpret this phenomenon; the first is the possibility that the selection has favoured the formation of numerous small seeds and second that selection promoting, as secondary adaptation for a large number of ovules, the agglutination of pollen grains that ensure their fertilization (Johnson and Edwards 2000).

During the evolution of Epidendroideae, the unilocular condition of the ovary (Fig. 6) is probably very advantageous for pollination, given the high number of ovules (usually over 100) attached to the placenta. The presence of a spacious area within the carpel facilitates the growth of the many pollen tubes formed by the pollen grains agglutinated in the pollinia (Rudall et al. 2002). It is expected that genera having the highest values of ovules, and a diffuse placenta have much more success in the fertilization (e.g. Epipactis, Corallorhiza, Spathoglottis, Dryadella, Masdevallia and Trisetella) than other Epidendroideae having pistils with linear placenta (one or two rows) in an area along the placenta of the ovary.

Another interesting characteristic is the presence of intraovarian trichomes. In this study, intra-ovarian trichomes were observed in subtribes Coeliopsidinae and Aeridinae. The intra-ovarian trichomes appeared on the placenta of ovules with poorly differentiated cells located in the midovary region of Vanda. To describe the type of trichomes, we considered the theories proposed by some authors that indicate that the development of the ovary occurs after fertilization (Clifford and Owens 1990; Zhang and O'Neill 1993; Tsai et al. 2008; Mayer et al. 2011). In addition, Zhang and O'Neill (1993) described the development of hair cells emerging from the endocarp after pollination during the development of the fruit. Similarly, Mayer et al. (2011) also described the presence of endocarpic trichomes in fruits of Oncidium flexuosum only after pollination. However, in this study, only ovaries at different floral stages were studied and not fruits.

In Orchidaceae, the subject of intra-ovarian and endocarpic trichomes has scarcely been addressed so far; they have been described in Aeridiinae (Hallé 1986), in Angraecinae (Freudenstein and Rasmussen 1999), and in Oncidium flexuosum (Mayer et al. 2011). They have also been studied in other monocotyledons, such as Asteliaceae belonging to Asparagales (Rudall et al. 1998). In this last case, they have been associated with the production of mucilage that covers the entire cavity of the ovary. Likewise, the trichomes located in the placenta have been reported for both monocotyledons (Araceae (French 1987)) and dicotyledons [e.g.
Salicaceae, Sapotaceae, Urticaceae, and Euphorbiaceae (Maheshwari 1950; Nagaraj 1952; Steyn et al. 1991)].

The results of our investigation indicate that pistils in the subfamily Epidendroideae are formed by three carpels divided into six valves, but only half of the six alternating valves are fertile. However, the pistils of Cattleya and Sophronitis have a very different pattern from the other Epidendroideae. Only the fertile carpels are well distinguished. We interpret that small sterile valves are located between the fertile valves and it seems to have pistils with three carpels (Fig. 5a). Probably, this uncommon type of pistil represents an intermediate state between pistils with three carpels and pistils with three carpels divided into six valves. Further investigation into this aspect is necessary to determine if this organization is the result of the decrease in the number of the valves or the division of the carpels. The number of carpels forming the pistil in Orchidaceae has been controversial. The presence of six carpels has been mentioned as a characteristic of the family (Vermeulen 1966; Puri 1951), but it has also been indicated that there is no evidence that the gynoecium consists of six carpels (Kurzweil 1998). Rasmussen and Johansen (2006) showed that in some cases the pistil is divided into six valves and, when this happens, the three sterile valves correspond to a sepal base and the three fertile ones to a petal base. In other cases such as subfamily Apostasioideae only three fertile carpels have been reported (Kocyan and Endress 2001; Mosquera-Mosquera et al. unpublished data).

All these carpel structural changes in Epidendroideae are clear evidence of the evolutionary trends in the ontogeny of Orchidaceae, from three isomorphic carpels, in some Cypripedioideae and Apostasioideae, to six well-defined heteromorphic valve carpels in most of the Epidendroideae taxa studied here. Probably, the division of the ovary into these six valves is the result of a late development in ontogeny (Kurzweil 1998).

The study of the anatomy of the pistil in Epidendroideae revealed variations in the vascular tissue organization. Poorly vascularized carpels (with a single ventral bundle) are predominant. On the contrary, Trichocentrum, Stanhopea, and Trigonidium present highly vascularized carpels (with ventral, dorsal, and lateral vascular bundles). Swamy (1948) asserted something similar about the more primitive Apostasioideae and Cypripedioideae orchids: Six vascular bundles from the inflorescence axis enter and cross the pistil longitudinally. In other subfamilies, such as Epidendroideae, only three vascular bundles of the inflorescence axis reach the floral axis, then branching in each genus or species in a different way (Swamy 1948; Rao 1974).

Another component of the vascular system is represented by the lateral vascular bundles, which are located on the periphery of the carpels or are dispersed without following a regular pattern. These are smaller than the dorsal and ventral 


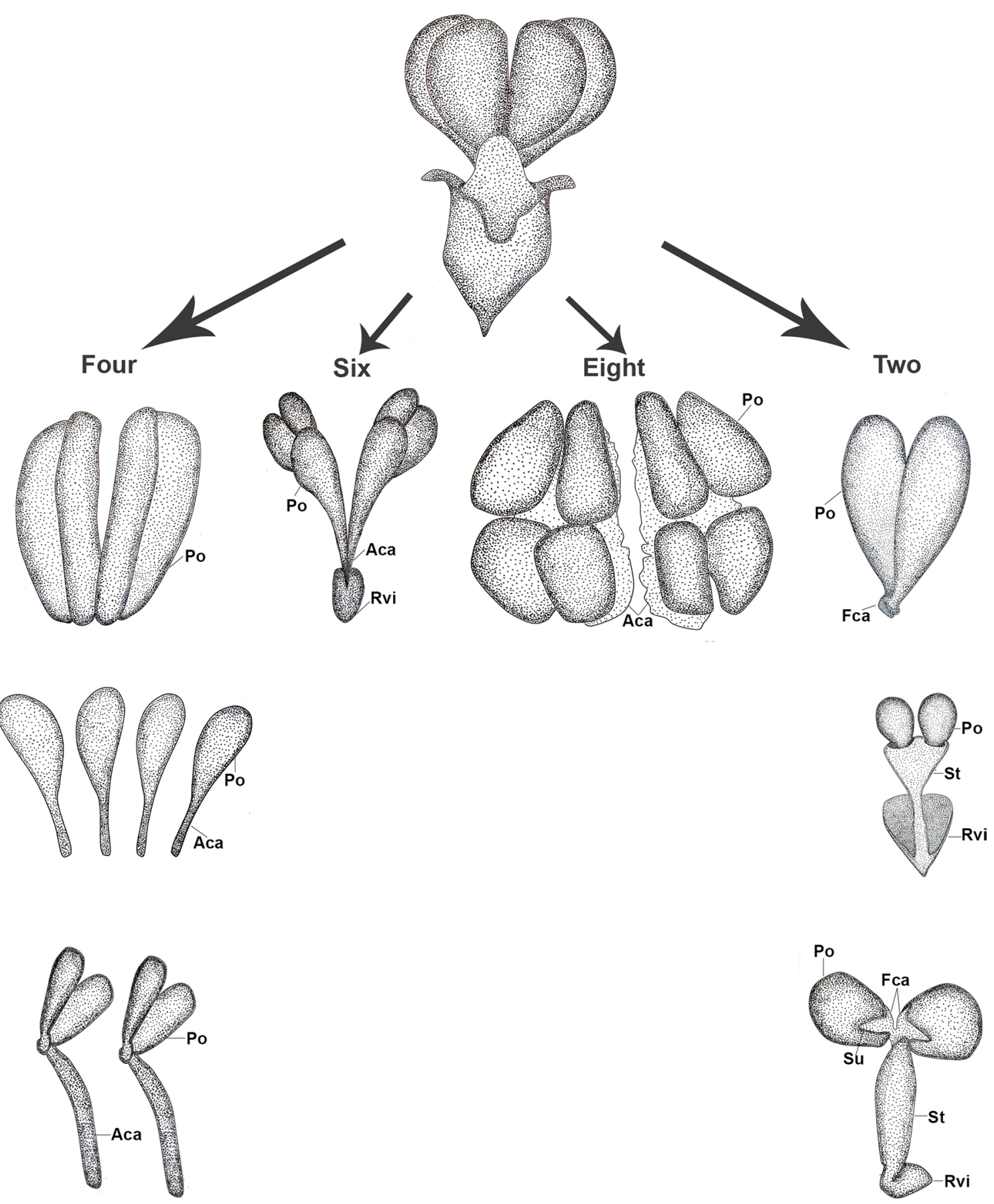

Fig. 8 Evolutionary trend in the number of pollinia and accessories structures of Epidendroideae. Po pollinium, Su suture, St stipe, Aca appendiculae caudicle, $F c a$ frenicular caudicle, $R v i$ removable viscidium

bundles and arise from the branching of the dorsal vascular bundles (Hardy and Stevenson 2000). It can be inferred that the abundant vascularization in taxa presenting ventral, dorsal, and lateral vascular bundles (e.g. Catasetum, Cattleya, Anguloa, Lycaste, Maxillaria, Sievekingia) is different from the plesiomorphic state—high vascularization lacking lateral vascular bundles-present in the most basal orchid genera (Apostasia, Neuwiedia, and Selenipedium) suggested by Rao (1974). On the contrary, abundant vascularization in Epidendroideae is a derived condition related to carpels with thick parenchyma. The detailed study of the vascularization of the Cypripedioideae, Apostasioideae, and Vanilloideae 
and also Orchidoideae and Epidendroideae clearly showed that there is no direct relationship between the first and the second groups, since in the latter there are patterns of high complexity associated with a large diversity that is reflected in the floral characters (Swamy 1948).

\section{Trends in character evolution}

The four reconstructed pollinia characters (number, orientation, texture, and the presence of suture in the pollinium) vary in Epidendroideae tribes and subtribes (Online Resource 2). The distribution of the character states across the subfamily could probably result from having evolved more than once in the subfamily.

Our results are consistent with the currently accepted systematic basis for the tribes and subtribes within Epidendroideae. The current taxonomic proposal is based on molecular data (Whitten et al. 2000; Pridgeon et al. 2001, 2003; Borba et al. 2002; van den Berg et al. 2005; Kułak et al. 2006; Sandoval-Zapotitla et al. 2010; Freudenstein and Chase 2015). In other cases, anatomical information of plant organs (Stern and Whitten 1999; Luo and Chen 2000; Stern and Judd 2001; Stern et al. 2004; Chase et al. 2008, 2009; Stern and Carlsward 2008) and palynological studies (Ackerman and Williams 1980; Hesse et al. 1989; Stenzel 2000) are also taken into account in the classification. Furthermore, in this study, we found that changes in the pollinarium and pistil are not linear and represent a contribution to understanding the evolution of the reproductive organs and a reconstruction of the pollinium character states permitting their evolution to be understood more clearly (Figs. 7, 8).

It has been hypothesized that the rapid radiation of Epidendroideae is probably associated with a specialization in pollination syndromes. As a result, this group has a mosaic of primitive and derivative morphological and molecular characters, with few autapomorphies and fewer synapomorphies (Cameron et al. 1999; Chase et al. 2003; Rothacker 2007; Whitten et al. 2014). The continuous structural changes in the pistil and orchid pollinarium establish a much narrower connection with specific animal pollinators, which could lead to the elimination of competition between and within taxa of this family. Although the impressive floral diversity of orchids has been attributed to the adaptation to specific pollinators the diversity is higher in species sharing a pool of generalist pollinators (e.g. Johnson et al. 1998; Cozzolino et al. 2004).

\section{Conclusions}

The characteristics of the pollen and pistil studied here have partly improved the understanding of how the states of these characteristics have changed in the subfamily
Epidendroideae, the transformations of the pollinarium and pollinium being more complex compared to the pistil (a unilocular ovary of three carpels divided into six valves). The results of this study allow the following conclusions to be drawn: It is demonstrated that the evolution of the characteristics of the pollinarium, pollinium, and pistil in Epidendroideae has not taken place in a linear form; on the contrary, probably, both reproductive structures have undergone reversions on more than one occasion in every tribe and subtribe. A primitive characteristic state (e.g. four granular pollinia) is present in the tribe Neottieae that in molecular analyses diverges early. In contrast, the subtribe Oncidiinae combines the most evolved characters in the pollinarium (two compact pollinia with suture), having also high taxonomic diversity. Epidendroideae presents the most evolved state in the number of carpels (three carpels divided into six valves), although some evidence observed (e.g. high reduction of the sterile valves) in Cattleya and Sophronitis indicates the tendency for reduction to only three, a condition that has been observed in the primitive subfamilies Cypripedioideae and Apostasioideae. The most frequent state in Epidendroideae is the unilocular pistil, only Peristeria and Huntleya having placental projections that seem to form three false locules. The number of locules of the pistil could have changed from one to three by developing the placenta and reversely from three to one by its retraction.

Epidendroideae presents a great variability in the characters of the pollinarium, showing primitive and advanced character states. This should be a response to the adaptation for the great number and diversity of pollinators, which disperse the pollinarium.

Acknowledgements We thank the Technological University of Chocó (Colombia) and the Spanish Foundation Carolina, which partially subsidized the doctoral studies of HR Mosquera-Mosquera. Special thanks are due to the Colombian Orchid Society (SCO) for funding and providing samples for this research. The authors thank Rafael Geovo (Istmina-Chocó, Colombia) and Roberto de Angulo Blum (Popayan, Colombia), owners of private collections of orchids, for their unconditional support and gifts of living material. The authors also thank the directors and curators of the Herbaria CHOCO, COL, HPUJ, HUA, and JAUM, K, and MA, for providing samples for our research, and Cristian D. Gaitan for drawing the illustrations. We are also grateful to the editor and reviewers for their critical comments and helpful suggestions for the manuscript. We sincerely thank Professor Felix Llamas (University of Leon) for his constant advice, collaboration, and the review of the several versions of this work, and Ms. Elizabeth Bailey for English language editing.

\section{Compliance with ethical standards}

Conflict of interest The authors declare that they have no conflict of interest.

Open Access This article is distributed under the terms of the Creative Commons Attribution 4.0 International License (http://creativeco 
mmons.org/licenses/by/4.0/), which permits unrestricted use, distribution, and reproduction in any medium, provided you give appropriate credit to the original author(s) and the source, provide a link to the Creative Commons license, and indicate if changes were made.

\section{Information on Electronic Supplementary Mate- rial}

Online Resource 1. Material studied, indicating taxonomy, voucher information (if exists) or references and GenBank accession numbers for each sequence download.

Online Resource 2. Floral characters to study the variation in the subfamily Epidendroideae and the reconstruction of ancestral states.

Online Resource 3. Matrix of Characters and states of the pistil and pollinaria of members of Orchidaceae.

Online Resource 4. Maximum likelihood values for the most parsimonious ancestral states for the MRCA of Epidendroideae clades.

\section{References}

Ackerman JD, Williams NH (1980) Pollen morphology of the tribe Neottieae and its impact on the classification of the Orchidaceae. Grana 19:7-18. https://doi.org/10.1080/00173138009424982

Arber A (1925) Monocotyledons: a morphological study. Cambridge University Press, London

Atwood JT (1984) The relationships of the slipper orchids (subfamily Cypripedioideae, Orchidaceae). Selbyana 7:129-247

Barone Lumaga MR, Cozzolino S, Kocyan A (2006) Exine micromorphology of Orchidinae (Orchidoideae, Orchidaceae): phylogenetic constraints or ecological influences? Ann Bot (Oxford) 98:237-244. https://doi.org/10.1093/aob/mcl094

Becerra GE (2005) El género Brachionidium (Orchidaceae) en el Perú. Tres especies nuevas para la selva central peruana. Arnaldoa 12:54-61

Bhanwra RK, Vij SP, Chandel V, Kant R, Dutt S (2006) Development of pollinium in two Epidendroid orchids. Curr Sci 90:1384-1388

Blackman SJ, Yeung EC (1983) Structural development of the Caudicle of an Orchid (Epidendrum). Amer J Bot 70:97-105. https://doi. org/10.1002/j.1537-2197.1983.tb12437.x

Borba EL, Shepherd GJ, van Den Berg C, Semir J (2002) Floral and vegetative morphometrics of five Pleurothallis (Orchidaceae) species: correlation with taxonomy, phylogeny, genetic variability and pollination systems. Ann Bot (Oxford) 90:219-230. https ://doi.org/10.1093/aob/mcf168

Burns-Balogh P (1983) A theory on the evolution of the exine in Orchidaceae. Amer J Bot 70:1304-1312. https://doi. org/10.1002/j.1537-2197.1983.tb07920.x

Burns-Balogh P, Funk VA (1986) A phylogenetic analysis of the orchidaceae. Smithsonian Contr Bot 61:1-79. https://doi.org/10.5479/ si.0081024X.61

Cameron KM (2003) The structure and occurrence of trilocular ovaries within Orchidaceae. The Lewis B. and Dorothy Cullman Program for Molecular Systematics Studies, The New York Botanical Garden, Bronx

Cameron KM, Chase MW, Whitten WM, Kores PJ, Jarrell DC, Albert VA, Yukawa T, Hills HG, Goldman DH (1999) A phylogenetic analysis of the Orchidaceae: evidence from $r b c L$ nucleotide sequences. Amer J Bot 86:208-224. https://doi. org/10.2307/2656938

Chase MW (2009) A new name for the single species of Nohawilliamsia and corrections in Gomesa (Orchidaceae). Phytotaxa 1:57-59. https://doi.org/10.11646/phytotaxa.1.1.6
Chase MW, Cameron KM, Barrett RL, Freudenstein JV (2003) DNA data and Orchidaceae systematics: a new phylogenetic classification. In: Dixon KM, Kell SP, Barret RL, Cribb PJ (eds) Orchid conservation. Natural History Publications, Kota Kinabalu, pp 69-89

Chase MW, Williams NH, Neubig KM, Whitten WM (2008) Taxonomic transfers in Oncidiinae to accord with genera orchidacearum. Lindleyana 5:20-31

Chase MW, Williams NH, de Faria AD, Neubig KM, Amaral MCE, Whitte WM (2009) Floral convergence in Oncidiinae (Cymbidieae; Orchidaceae): an expanded concept of Gomesa and a new genus Nohawilliamsia. Ann Bot (Oxford) 104:387-402. https:// doi.org/10.1093/aob/mcp067

Chase MW, Cameron KM, Freudenstein JV, Pridgeon AM, Salazar G, van Den Berg C, Schuiteman A (2015) An updated classification of Orchidaceae. Bot J Linn Soc 177:151-174. https://doi. org/10.1111/boj.12234

Claessens J, Kleynen J (1998) Column structure and pollination of Corallorrhiza trifida Châtelain (Orchidaceae). J Eur Orch 30:629-637

Clifford SC, Owens SJ (1990) The stigma, style and ovarian transmitting tract in the Oncidiinae (Orchidaceae): morphology, developmental anatomy, and histochemistry. Bot Gaz 151:440-451

Cozzolino S, D'Emerico S, Wldmer A (2004) Evidence for reproductive isolate selection in Mediterranean orchids: karyotype differences compensate for the lack of pollinator specificity. Proc Roy Soc London B (Suppl) 271:259-262. https://doi.org/10.1098/ rsbl.2004.0166

Cribb PJ (1999) Morphology. In: Pridgeon AM, Cribb PJ, Chase MW, Rasmussen FN (eds) Genera orchidacearum, vol 1. General introduction, apostasioideae, cypripedioideae. Oxford University Press, Oxford, pp 13-23

Damon A, Nieto G (2012) A guide to the morphology of the pollinia and pollinaria of Orchids from the Biological Corridor TacanáBoquerón in southeast Mexico. Selbyana 31:5-39

Dathe S, Dietrich H (2006) Comparative molecular and morphological studies in selected Maxillariinae orchids. Willdenowia 36:89102. https://doi.org/10.3372/wi.36.36106

Dressler RL (1981) The orchids: natural history and classification. Harvard University Press, Cambridge

Dressler RL (1986) Feature of pollinaria and orchid classification. Lindleyana 1:125-130

Dressler RL (1993) Phylogeny and classification of the orchid family. Dioscorides Press, Portland

Dressler RL, Dodson CH (1960) Classification and phylogeny in the Orchidaceae. Ann Missouri Bot Gard 47:25-68

Endress PK (2011) Angiosperm ovules: diversity, development, evolution. Ann Bot (Oxford) 107:1465-1489

French JC (1987) Structure of ovular and placental trichomes of Araceae. Bot Gaz 148:198-208

Freudenstein JV (1994) Gynostemium structure and relationships of the Corallorhizinae (Orchidaceae: Epidendroideae). Pl Syst Evol 193:1-19. https://doi.org/10.1007/bf00983537

Freudenstein JV, Chase MW (2015) Phylogenetic relationships in Epidendroideae (Orchidaceae), one of the great flowering plant radiations: progressive specialization and diversification. Ann Bot (Oxford) 115:665-681. https://doi.org/10.1093/aob/mcu253

Freudenstein JV, Rasmussen FN (1996) Pollinium development and number in the Orchidaceae. Amer J Bot 83:813-824. https://doi. org/10.1002/j.1537-2197.1996.tb12773.x

Freudenstein JV, Rasmussen FN (1997) Sectile pollinia and relationships in the Orchidaceae. Pl Syst Evol 205:125-146

Freudenstein JV, Rasmussen FN (1999) What does morphology tell us about Orchid relationships? A cladistic analysis. Amer J Bot 86:225-248. https://doi.org/10.2307/2656939 
Freudenstein JV, Harris EM, Rasmussen FN (2002) The evolution of anther morphology in orchids: incumbent anthers, superposed pollinia, and the Vandoid complex. Amer J Bot 89:1747-1755. https://doi.org/10.3732/ajb.89.11.1747

Freudenstein JV, Yukawa T, Luo YB (2017) A reanalysis of relationships among Calypsoinae (Orchidaceae: Epidendroideae): floral and vegetative evolution and the placement of Yoania. Syst Bot 42:17-25. https://doi.org/10.1600/036364417x694944

Garay LA (1960) On the origin of the Orchidaceae. Bot Mus Leafl 19:57-96

Gasser CS, Robinson-Beers K (1993) Pistil development. Pl Cell 5:1231-1239. https://doi.org/10.1105/tpc.5.10.1231

Gustafson MHG (1995) Petal venation in the Asterales and related orders. Bot J Linn Soc 118:1-18. https://doi.org/10.1006/ boj1.1995.0024

Hallé N (1986) Les élatères des Sarcanthinae et additions aux Orchidaceae de la Nouvelle-Calédonie. Bull Mus Natl Hist Nat B Adansonia 3:215-239. https://doi.org/10.5252/a2016n2a4

Harder LD, Johnson SD (2008) Function and evolution of aggregated pollen in Angiosperms. Int J Pl Sci 169:59-78. https://doi. org/10.1086/523364

Hardy CR, Stevenson DW (2000) Floral organogenesis in some species of Tradescantia and Callisia (Commelinaceae). Int J Pl Sci 161:551-562. https://doi.org/10.1086/314279

Hesse M, Burns-Balogh P, Wolff M (1989) Pollen morphology of the "primitive" epidendroid orchids. Grana 28:261-268. https://doi. org/10.1080/00173138909427440

Hidayat T, Yukawa T, Ito M (2006) Evolutionary analysis of pollinaria morphology of subtribe Aeridinae (Orchidaceae). Reinwardtia 12:223-235. https://doi.org/10.14203/reinwardtia.v12i3.65

Inda LA, Pimentel M, Chase MW (2010) Contribution of mitochondrial $\operatorname{cox} 1$ intron sequences to the phylogenetics of tribe Orchideae (Orchidaceae): do the distribution and sequence of this intron in orchids also tell us something about its evolution? Taxon 59:1053-1064. https://doi.org/10.2307/20773976

Inda LA, Pimentel M, Chase MW (2012) Phylogenetics of tribe Orchideae (Orchidaceae: Orchidoideae) based on combined DNA matrices: inferences regarding timing of diversification and evolution of pollination syndromes. Ann Bot (Oxford) 110:7190. https://doi.org/10.1093/aob/mcs083

Johnson SD, Edwards TJ (2000) The structure and function of orchid pollinaria. Pl Syst Evol 222:243-269. https://doi.org/10.1007/ bf00984105

Johnson SD, Linder HP, Steiner KE (1998) Phylogeny and radiation of pollination systems in Disa (Orchidaceae). Amer J Bot 85:402411. https://doi.org/10.2307/2446333

Kant R, Hossain MM, Attri LK (2013) Pollinium development in Spiranthes sinensis (Pers.) Ames and Cymbidium pendulum SW: a comparative study. Bangaldesh J Bot 42:307-314. https://doi. org/10.3329/bjb.v42i2.18035

Keng H, Chin SC, Tan HTW (1998) The concise flora of Singapore. Volume 2: Monocotyledons. Singapore University Press, National University of Singapore, Singapore

Kocyan A (2007) The discovery of polyandry in Curculigo (Hypoxidaceae). Implications for androecium evolution of Asparagoid Monocotyledons. Ann Bot (Oxford) 100:241-248. https://doi. org/10.1093/aob/mcm091

Kocyan A, Endress PK (2001) Floral structure and development of Apostasia and Neuwiedia (Apostasioideae) and their relationships to other Orchidaceae. Int J Pl Sci 162:847-867. https://doi. org/10.1086/320781

Kocyan A, Snijman DA, Forest F, Devey DS, Freudenstein JV, WilandSzymańska J, Chase MW, Rudall PJ (2011) Molecular phylogenetics of Hypoxidaceae: evidence from plastid DNA data and inferences on morphology and biogeography. Molec Phylogent Evol 60:122-136. https://doi.org/10.1016/j.ympev.2011.02.021
Kułak M, Górniak M, Romowicz A (2006) Tribal and subtribal relationship of Epidendroideae Lindl. (Orchidaceae) with emphasis on Epidendreae Humb., Bonpl. and Kunth based on matK gene. Biodivers Res Conservation 3-4:205-209

Kurzweil H (1987a) Developmental studies in orchid flowers. I: Epidendroid and vandoid species. Nordic J Bot 7:427-442. https:// doi.org/10.1111/j.1756-1051.1987.tb00964.x

Kurzweil H (1987b) Developmental studies in orchid flowers. II: Orchidoid species. Nordic J Bot 7:443-451. https://doi. org/10.1111/j.1756-1051.1987.tb00965.x

Kurzweil H (1988) Developmental studies in orchid flowers. III: Neottioid species. Nordic J Bot 8:271-282. https://doi. org/10.1111/j.1756-1051.1988.tb01721.x

Kurzweil H (1998) Floral ontogeny of orchids: a review. Beitr Biol Pflanzen 7:45-100

Lavarack PS (1971) The taxonomic affinities of the Neottioideae. PhD Thesis, University of Queensland, Saint Lucia. https://doi. org/10.14264/uq1.2015.60

Li YY, Chen XM, Guo SX, Lee YI (2016) Embryology of two mycoheterotrophic orchid species, Gastrodia elata and Gastrodia nantoensis: ovule and embryo development. Bot Stud 57:1-10. https ://doi.org/10.1186/s40529-016-0137-7

Lindley J (1830-1840) The genera and species of orchidaceous plants. Ridgways, Piccadilly, London

Lindley J (1847) The vegetative kingdom, 2nd edn. Bradbury and Evans, London

Luo YB, Chen SC (2000) The floral morphology and ontogeny of some Chinese representatives of orchid subtribe Orchidinae. Bot J Linn Soc 134:529-548. https://doi.org/10.1111/j.1095-8339.2000. tb00549.x

Maddison WP, Maddison DR (2014) Mesquite: a modular system for evolutionary analysis. Version 2.75. Available at: http://mesqu iteproject.org. Accesed 29 Apr 2017

Maheshwari P (1950) An introduction to the embryology of angiosperms. McGraw-Hill, New York

Mansfeld R (1935) Orchideologische Mitteilungen. III. 21. Zur terminologie der pollinienanhiingsel der orchideen. Repert Spec Nov Regni Veg 38:199-202

Mayer JL, Carmello-Guerreiro SM, Appezzato-da-Glória B (2011) Anatomical development of the pericarp and seed of Oncidium flexousum Sims (Orchidaceae). Flora 206:601-609. https://doi. org/10.1016/j.flora.2011.01.009

Miller MA, Pfeiffer W, Schwartz T (2010) Creating the CIPRES science gateway for inference of large phylogenetic trees. In: Proceedings of the gateway computing environments workshop (GCE), New Orleans. pp 1-8

Nagaraj M (1952) Floral morphology of Populus deltoides and $P$. tremuloides. Bot Gaz 114:222-243

Nieto G, Damon A (2008) Guide to the morphology of the pollinia and pollinaria of orchids from southeast Mexico. Selbyana 29:20-68

Pacini E, Hesse M (2002) Types of pollen dispersal units in orchids, and their consequences for germination and fertilization. Ann Bot (Oxford) 89:653-664. https://doi.org/10.1093/aob/mcf138

Pansarin ER, Estanislau do Amaral MC (2008) Pollen and nectar as a reward in the basal Epidendroid Psilochilus modestus (Orchidaceae: Triphoreae): a study of floral morphology, reproductive biology and pollination strategy. Flora 203:474-483. https://doi. org/10.1016/j.flora.2007.07.004

Pedersen HA, Watthana S, Srimuang KO (2013) Orchids in the torrent: on the circumscription, conservation and rheophytic habit of Epipactis flava. Bot J Linn Soc 172:358-370. https://doi. org/10.1111/boj.12023

Peter CI, Johnson SD (2006) Doing the twist: a test of Darwin's crosspollination hypothesis for pollinarium reconfiguration. Biol Lett 2:65-68. https://doi.org/10.1098/rsbl.2005.0385 
Pridgeon AM, Solano R, Chase MW (2001) Phylogenetic relationships in Pleurothallidinae (Orchidaceae): combined evidence from nuclear and plastid DNA sequences. Amer J Bot 88:2286-2308. https://doi.org/10.2307/3558390

Pridgeon AM, Cribb PJ, Chase MW, Rasmussen FN (2003) Genera orchidacearum. Volume 3: Orchidoideae (part 2): Vanilloideae. Oxford University Press, Oxford. https://doi.org/10.1086/421617

Puri V (1951) The role of floral anatomy in the solution of morphological problems. Bot Rev 17:472-534

Ramírez SR, Gravendeel B, Singer RB, Marshall CR, Pierce NE (2007) Dating the origin of the Orchidaceae from a fossil orchid with its pollinator. Nature 448:1042-1045. https://doi. org/10.1038/nature06039

Rao VS (1974) The relationships of the Apostasiaceae on the basis of floral anatomy. Bot J Linn Soc 68:319-327. https://doi. org/10.1111/j.1095-8339.1974.tb01982.x

Rasmussen FN (1982) The gynostemium of the Neottioid Orchids. Opera Bot 65:1-96

Rasmussen FN (1986) On the various contributions by which pollinia are attached to viscidia. Lindleyana 1:21-32

Rasmussen FN, Johansen B (2006) Carpology of orchids. Selbyana 27:44-53. https://doi.org/10.2307/41760259

Reichenbach HG (1854) Orchideae Schlimianae. Bonplandia 2:277-284

Rothacker EP (2007) The primitive Epidendroideae (Orchidaceae): phylogeny, character evolution and the systematic of Psilochilus (Triphoreae). PhD Thesis, The Ohio State University, Columbus

Rudall PJ, Bateman RM (2002) Roles of synorganisation, zygomorphy and heteromorphy in floral evolution: the gynostemium and labellum of orchids and other lilioid monocots. Biol Rev 77:403-441. https://doi.org/10.1017/s 1464793102005936

Rudall PJ, Prychid CJ, Jones C (1998) Intra-ovarian trichomes, mucilage secretion and hollow styles in monocotyledons. In: Owens SJ, Rudall PJ (eds) Reproductive biology. Royal Botanic Gardens, Kew, pp 219-230

Rudall PJ, Bateman RM, Fay MF, Eastman A (2002) Floral anatomy and systematics of Alliaceae with particular reference to Gilliesia, a presumed insect mimic with strongly zygomorphic flowers. Amer J Bot 89:1867-1883. https://doi.org/10.3732/ ajb.89.12.1867

Sáenz C (2004) Glosario de términos palinológicos. Lazaroa 25:93-112

Sagawa Y, Israel HW (1964) Post-pollination ovule development in Dendrobium Orchids. I. Introduction. Caryologia 17:53-64. https ://doi.org/10.1080/00087114.1964.10796116

Sandoval-Zapotitla E, Terrazas T, Villaseñor JL (2010) Diversidad de inclusiones minerales en la subtribu Oncidiinae (Orchidaceae). Rev Biol Trop 58:733-755

Saunders ER (1923) A reversionary character in the Stock (Matthiola incana) and its significance in regard to the structure and evolution of the gynoecium in the Rhoeadales, the Orchidaceae, and other families. Ann Bot (Oxford) 37:451-482. https://doi. org/10.1093/oxfordjournals.aob.a089859

Schill R, Pfeiffer W (1977) Untersuchungen an orchideenpollinien unter besonderer beruecksichtigung ihrer feinskulpturen. Pollen Spores 19:5-118

Schill R, Dannenbaum C, Neyer P (1992) Quantitative Untersuchungen an Orchideen-pollinien. Bot Jahrb Syst 114:153-171

Seidenfaden G, Wood JJ (1992) The Orchids of peninsular Malaysia and Singapore. A revision of R.E. Holttum: Orchids of Malaya. The Royal Botanical Garden, Kew \& Botanic Gardens, Singapore

Senghas K (1993) Subtribus Maxillariinae. In: Brieger FG, Maatsch R, Senghas K (eds) Rudolf Schlechter: Die Orchidee. Blackwell Wissenschafts, Berlin
Sing-Chi Ch (1982) The origin and early differentiation of the Orchidaceae. Acta Phytotax Sin 20:1-22

Singer RB, Koehler S (2004) Pollinarium morphology and floral rewards in Brazilian Maxillariinae (Orchidaceae). Ann Bot (Oxford) 93:39-51. https://doi.org/10.1093/aob/mch009

Singer RB, Gravendeel B, Cross H, Ramírez SR (2008) The use of orchid pollinia or pollinaria for taxonomic identification. Selbyana 29:6-19. https://doi.org/10.2307/41760315

Solis SM, Ferrucci MS (2009) Patrones de venación floral en tres especies de Paullinieae (Sapindaceae). Bol Soc Argent Bot 44:317-327

Stenzel H (2000) Pollen morphology of the subtribe Pleurothallidinae Lindl. (Orchidaceae). Grana 39:108-125. https://doi. org/10.1080/001731300300045247

Sterling C (1974) Comparative morphology of the carpel in the Liliaceae: Baeometra, Burchardia and Walleria. Bot J Linn Soc 68:115-125. https://doi.org/10.1111/j.1095-8339.1974.tb01752.x

Sterling C (1977) Comparative morphology of the carpel in the Liliaceae: Uvularieae. Bot J Linn Soc 74:63-69. https://doi. org/10.1111/j.1095-8339.1977.tb01186.x

Sterling C (1978) Comparative morphology of the carpel in the Liliaceae: Hewardieae, Petrosavieae and Tricyrteae. Bot J Linn Soc 77:95-106. https://doi.org/10.1111/j.1095-8339.1978.tb01375.x

Stern WL (2014) Orchidaceae. In: Gregory M, Cutler DF (eds) Anatomy of the monocotyledons, vol. X. Oxford University Press, Oxford

Stern WL, Carlsward BS (2008) Vegetative anatomy of Calypsoeae (Orchidaceae). Lankesteriana 8:105-112. https://doi. org/10.15517/lank.v8i3.18324

Stern WL, Judd W (2001) Comparative anatomy and systematics of Catasetinae (Orchidaceae). Bot J Linn Soc 136:153-178. https ://doi.org/10.1006/boj1.2000.0439

Stern WL, Whitten WM (1999) Comparative vegetative anatomy of Stanhopeinae (Orchidaceae). Bot J Linn Soc 129:87-103. https ://doi.org/10.1006/boj1.1998.0229

Stern WL, Cheadle VI, Thorsch J (1993) Apostasiads, systematic anatomy, and the origins of Orchidaceae. Bot J Linn Soc 111:411455. https://doi.org/10.1111/j.1095-8339.1993.tb01913.x

Stern WL, Judd W, Carlsward BS (2004) Systematic and comparative anatomy of Maxillarieae (Orchidaceae), sans Oncidiinae. Bot J Linn Soc 144:251-274. https://doi.org/10.111 1/j.1095-8339.2003.00257.x

Steyn EMA, Robbertse PJ, Coetzer LA (1991) Intra-ovarian trichomes in Bequaertiodendron megalismontanum: Location, origin, structure and possible function in the reproductive process. S African J Bot 57:191-197

Stöver BC, Müller KF (2010) TreeGraph 2: combining and visualizing evidence from different phylogenetic analyses. BMC Bioinf 11:7. https://doi.org/10.1186/1471-2105-11-7

Swamy BG (1948) Vascular anatomy of orchid flowers. Bot Mus Leafl 13:61-95

Swamy BG (1949) Embryological studies in the Orchidaceae. II. Embryogeny. Amer Midl Naturalist 41:202-232

Szlachetko DL (2003) Gynostemia orchidalium III. Acta Bot Fenn 176:1-311

Szlachetko DL, Margońska HB (2002) Gynostemia orchidalium IV. Acta Bot Fenn 173:1-275

Szlachetko DL, Mytnik-Ejsmont J (2009) Gynostemia orchidalium IV. Acta Bot Fenn 180:1-313

Szlachetko DL, Rutkowski P (2000) Gynostemia orchidalium IV. Acta Bot Fenn 169:1-380

Szlachetko DL, Mytnik-Ejsmont J, Romowicz A (2006) Genera et species orchidalium. 14. Oncidieae. Polish Bot J 51:53-55

Szlachetko DL, Sitko M, Tukałło P, Mytnik-Ejsmont J (2012) Taxonomy of the subtribe Maxillariinae (Orchidaceae, Vandoideae) 
revised. Biodivers Res Conservation 25:13-138. https://doi. org/10.2478/v10119-012-0017-2

Trapnell DW, Hamrick JL (2006) Floral display and mating patterns within populations of the neotropical epiphytic orchid Laelia rubescens (Orchidaceae). Amer J Bot 93:1010-1018. https://doi. org/10.3732/ajb.93.7.1010

Tsai WC, Hsiao YY, Pan ZJ, Kuoh CS, Chen WH, Chen HH (2008) The role of ethylene in orchid ovule development. Pl Sci 175:98105. https://doi.org/10.1016/j.plantsci.2008.02.011

van Den Berg C, Goldman DH, Freudenstein JV, Pridgeon AM, Cameron KM, Chase MW (2005) An overview of the phylogenetic relationships within Epidendroideae inferred from multiple DNA regions and recircumscription of Epidendreae and Arethuseae (Orchidaceae). Amer J Bot 92:613-624. https://doi.org/10.3732/ ajb.92.4.613

Vermeulen P (1966) The system of the orchidales. Acta Bot Neerl 15:224-253. https://doi.org/10.1111/j.1438-8677.1966.tb00228.x

Veyret Y (1981) Quelques aspects du pistil et de son devenir chez quelques Sobraliinae (Orchidaceae) de Guyane. Bull Mus Natl Hist Nat B Adansonia 1:75-83

Walker DB (1975) Postgenital carpel fusion in Catharanthus roseus III. Fine structure of the epidermis during and after fusion. Protoplasma 86:43-63

Whitten WM, Williams NH, Chase MW (2000) Subtribal and generic relationships of Maxillarieae (Orchidaceae) with emphasis on Stanhopeinae: combined molecular evidence. Amer J Bot 87:1842-1856. https://doi.org/10.2307/2656837

Whitten WM, Neubig KM, Williams NH (2014) Generic and subtribal relationships in Neotropical Cymbidieae (Orchidaceae) based on matK/ycf1 plastid data. Lankesteriana 13:375-392. https://doi. org/10.15517/lank.v13i3.14425

Williams NH (1970) Some observations on pollinaria in the Oncidiinae I, II. Amer Orch Soc Bull 39:207-220

Xiang XG, Li DZ, Jin WT, Zhou HL, Li JW, Jin XH (2012) Phylogenetic placement of the enigmatic orchid genera Thaia and Tangtsinia: evidence from molecular and morphological characters. Taxon 61:45-54

Yeung EC, Law SK (1987) The formation of hyaline caudicle in two vandoid orchids. Canad J Bot 65:1459-1464. https://doi. org/10.1139/b87-201

Zhang XS, O’Neill SD (1993) Ovary and gametophyte development are coordinately regulated by auxin and ethylene following pollination. Pl Cell 5:403-418. https://doi.org/10.1105/tpc.5.4.403

Publisher's Note Springer Nature remains neutral with regard to jurisdictional claims in published maps and institutional affiliations. 